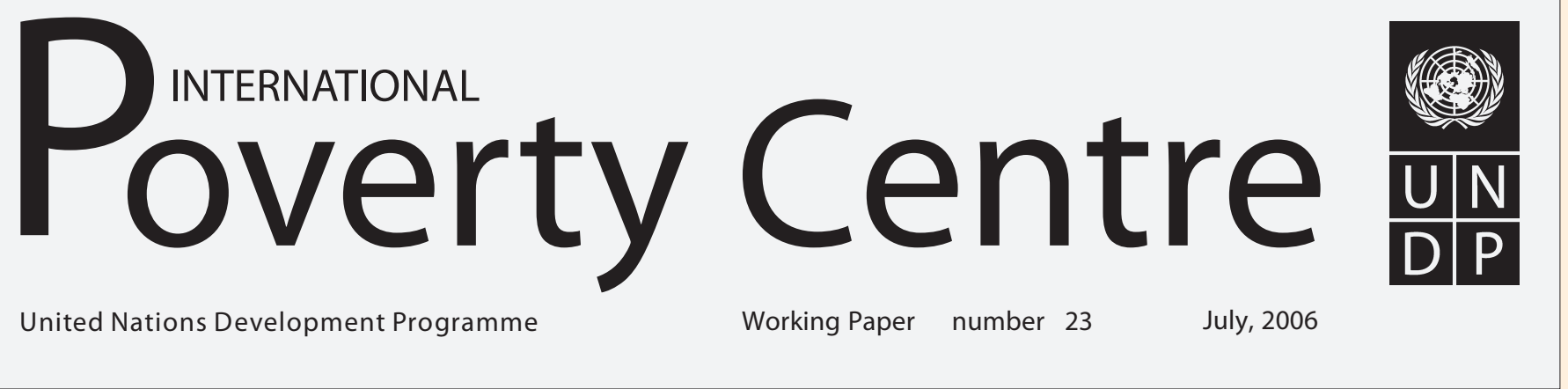

\title{
ADDRESSING GLOBAL IMBALANCES: A DEVELOPMENT-ORIENTED POLICY AGENDA
}

\author{
Alex Izurieta \\ Senior Researcher, Cambridge Endowment for Research in Finance, \\ University of Cambridge, United Kingdom \\ and \\ Terry McKinley \\ Senior Researcher and Acting Director, \\ International Poverty Centre, \\ United Nations Development Programme
}




\title{
Copyright $(2006$
}

United Nations Development Programme International Poverty Centre

\author{
International Poverty Centre \\ SBS - Ed. BNDES, $10^{\circ}$ andar \\ 70076900 Brasilia DF \\ Brazil \\ povertycentre@undp-povertycentre.org \\ www.undp.org/povertycentre \\ Telephone +55 6121055000 \\ Fax +556121055001
}

\section{Rights and Permissions}

All rights reserved.

The text and data in this publication may be reproduced as long as the source is cited.

Reproductions for commercial purposes are forbidden.

The International Poverty Centre's Working Papers disseminates the findings of work in progress to encourage the exchange of ideas about development issues. The papers are signed by the authors and should be cited and referred to accordingly. The findings, interpretations, and conclusions expressed in this paper are entirely those of the authors. They do not necessarily represent the views of the International Poverty Centre or the United Nations Development Programme, its Administrator, Directors, or the countries they represent.

Working Papers are available online at http://www.undp.org/povertycentre and subscriptions might be requested by email to povertycentre@undp-povertycentre.org 


\title{
ADDRESSING GLOBAL IMBALANCES: A DEVELOPMENT-ORIENTED POLICY AGENDA*
}

\author{
Alex Izurieta** and Terry McKinley ${ }^{* * *}$
}

\begin{abstract}
This working paper uses a revived 'world trade and income model' to examine three markedly different scenarios of the world economy. It presents criticisms of the first scenario, the 'Consensus Growth Forecast', which is an optimistic scenario for future global growth utilized by U.S. policymakers and international financial institutions. This forecast assumes that the gross macroeconomic imbalances currently plaguing the world economy will be resolved, in due course, by market forces-without recourse to major policy interventions. The working paper maintains, instead, that a second scenario-namely, a recession in the U.S. economy (precipitated by a drop in unsustainable household spending) and a marked slowdown in global growth-is much more plausible. In order to avoid such an adverse outcome, the working paper examines the feasibility of a third scenario, a 'Coordinated Growth Scenario'. The paper maintains that this scenario could launch the U.S. economy on a more sustainable economic path, increase growth in other developed countries and enable developing countries to benefit disproportionately, i.e., achieve rapid 'catch-up' rates of growth. This third scenario is based on more expansionary macroeconomic policies, increased investment in manufacturing capacities in developing countries, greater trade integration among developing countries and greater reliance on measures to promote energy savings. While the third scenario is both feasible and desirable, it will entail major structural changes and increased policy coordination across countries.
\end{abstract}

\footnotetext{
*This paper is an output of the long-term project "Globally Co-ordinated Strategies for Economic Development," which is carried out by the Cambridge Endowment for Research in Finance (CERF) and Alphametrics Ltd.. Contributions of Francis Cripps, including the Alphametrics' 'World Trade and Income Model' and his recent revisions of its framework are central to this research. Wynne Godley's pioneering insights into the U.S. economy and his innovative macro-modelling framework have been used extensively. Tugrul Vehbi has assisted this work from its inception, in all of its facets, with remarkable dedication and skills. The authors are grateful for all of these contributions. The usual disclaimer applies.

** Senior Researcher, Cambridge Endowment for Research in Finance, University of Cambridge, U.K.

*** Senior Researcher and Acting Director, International Poverty Centre, Brasilia.
} 


\section{INTRODUCTION}

This working paper draws on the research of a global project on macro-modelling spearheaded by the Cambridge Endowment for Research in Finance along with Alphametrics Inc. It has been supported from the beginning by the Poverty Group of the United Nations Development Programme and continues to be supported by the International Poverty Centre. The Centre supports this initiative because it believes that this research is extremely relevant to economic policymaking in both developing and developed countries. It will prove to be particularly useful, the Centre believes, for developing countries in formulating policy responses to the current context of world macroeconomic imbalances.

The core of the paper presents three different 'scenarios' for the world economy based on applying a world trade and income macroeconomic model. These three 'scenarios' are not forecasts; they are generated by the world macro model by making assumptions about basic macroeconomic parameters and then obliging the results to be consistent with recent historical trends and the current structure of the world economy. A brief description of the modelling methodology is presented in Section 2 while the details are elaborated in Appendix A.

Section 3 elaborates the three scenarios. The first scenario presents logically derived results for the U.S. economy, the world economy, and various regions and major countries if the current 'Consensus Forecast' — which embodies the prevailing optimistic projections of U.S. policymakers and multilateral financial institutions-is assumed. Although such a scenario is widely accepted, this paper regards it to be unrealistic.

Hence, this paper presents a second more 'realistic' scenario. In this case, a severe slowdown in the U.S. economy, precipitated by an abrupt decline in household spending, is assumed. Based on such a slowdown, the world macro model delineates the varying impacts on regions of the world and major countries. This scenario assumes, however, that there is no major change in policies in the United States or in the governing international policy regime.

The third scenario assumes a more optimistic, but feasible, scenario-which we call a 'Coordinated Growth Scenario'. Its feasibility is based, however, on major policy changes, such as 1) movements towards correcting severe current account imbalances among countries that run either a large current account deficit or a large current account surplus 2) progress in the transition in developing countries from the production of primary commodities to manufactures, buttressed by increased South-South trade integration and 3) increased energy efficiency (which we regard as essential to any optimistic scenario). This scenario represents, we believe, a 'winwin' option for both developing and developed countries, including the United States.

Section 4 of this paper presents conclusions on the modelling exercise, based principally on drawing the major policy lessons from the three scenarios.

\section{THE MODELLING APPROACH}

The empirical estimates in this Working Paper are based on two strands of modelling. Global patterns and simulations are based on a currently revised version of the Alphametrics' world trade and income model created in the 1980s by Francis Cripps and associates at the Cambridge Economic Policy Group (CEPG). Trends and extrapolations for the U.S. economy are derived from the modelling approach of Wynne Godley and the work developed at the Levy Economics Institute. 


\section{GENERATING PROJECTIONS FOR THE U.S. ECONOMY}

Macroeconomic projections for the U.S. are compiled first from documents produced by the U.S. administration and statistical offices (the Congressional Budget Office (CBO), 2006; the Council of Economic Advisors (CEA), 2006; the Bureau of Economic Analysis (BEA), and the statistics of the Federal Reserve) as well as institutions such as 'Consensus Economics'. ' These main projections are subsequently inputted into an accounting framework of flows and stocks, and trends are econometrically generated as a result of model solutions. Core to these estimates are the macroeconomic relations outlined in Godley and Cripps (1983), which are specified further in Godley (1999) for the U.S. economy (see also Godley, 2000; Godley and McCarthy, 1998; Godley and Izurieta, 2001; and Martin, 2001), and in a series of publications of the Levy Economics Institute (Papadimitriou, Shaikh, Santos and Zezza, 2003, 2004, 2005). Izurieta (2005) revised this framework by generating a consistent series of holding gains based on the asset and debt positions of U.S. institutional sectors.

\section{GENERATING SCENARIOS FOR THE WORLD ECONOMY}

The model originally constructed by Francis Cripps at the Cambridge Economic Policy Group is outlined in a series of technical papers (e.g., Alphametrics (1987), available upon request). This is now being updated and extended by the Cambridge Endowment for Research in Finance and Alphametrics, with support from the United Nations Development Programme, specifically the International Poverty Centre in Brasilia.

This new framework (the CERF-Alphametrics global model, henceforth designated as CAM) has features that were not in the original model. ${ }^{2}$ These include:

- Incorporation of financial stocks and flows into the existing model of world trade and income (i.e., the original Alphametrics model). This change allows analysis of the combined impact of fiscal, monetary and structural policies.

- Development of the model on three levels-the global, regional and country levels-in an 'open geometry' fashion. This allows researchers to examine the relationships among country, regional and global developments.

- Construction of a macro-econometric structure to provide historical analyses and 'what-if' scenarios for the world economy, major regions and countries.

The chief characteristics of the revised model that are used in the generation of scenarios for this working paper are as follows:

a) Domestic spending adjusts to stocks as well as flows (namely, spending is a function of both income and the accumulated stock of wealth).

A stable macroeconomic relationship between stocks and flows is postulated. Such a relationship can be measured by the 'mean-lag', or the average period of time for income to be fully spent (Godley and Cripps, 1983).

These basic propositions underlie the 'the Cambridge Expenditure Function,' which was at the centre of the controversy about macroeconomic adjustment in the 1970s and 1980s. Such postulates, with modifications that develop a more comprehensive concept of 'the stock of wealth' (e.g., that take into account lending, foreign inflows and holding gains), are also the core components of the model of the U.S. economy. 
Since the current CAM model does not account for stocks, the stock-flow relationship is imputed by assuming that the domestic propensity to spend out of income is, on average, close to one, with a significant mean lag.

The U.S. economy is an interesting case in this regard. Expenditure has deviated from the postulated 'stable' stock-flow relationship. The current account has been in deficit for a long time, and yet the domestic propensity to spend has remained greater than one. Two interpretations are possible: 1 ) there is a structural shift wherein the new U.S. pattern is to continue spending more than it receives in income, or 2) its position is not sustainable and the economy will return, some time soon, towards a stable pattern. We adopt the latter interpretation. Thus, our domestic expenditure function for the U.S. incorporates a limit derived from an assumed long-term ratio of wealth to income.

b) Stable stock-flow relations are evaluated, however, bloc by bloc, with differences specified for the mean lag and for the response of trade flows to expenditure.

c) Domestic spending is influenced by fiscal and monetary policies that respond to balance of payments pressures.

The pressure for adjustment is stronger for relatively underdeveloped countries and can be asymmetrical (i.e., upward adjustment to surplus is weaker than downward adjustment to deficit).

d) Productivity is highly responsive to demand, especially in open economies. Such productivity increases are 'Kaldorian' in essence: over time, they require economies of scale and specialization, sustained by the growth of markets (Kaldor, 1932, and more specifically, 1986).

e) An essential dimension of development is the switching of technology from tradeable primary commodities to tradeable manufactures, à la Lewis (1954). As development proceeds based on increases of productivity and intensification of specialization, resources are freed in the primary sector and channelled into the secondary sector. Growth of demand is necessary for this process to occur, as proposed in Kalecki (1976) and further formalized in FitzGerald (1993).

f) The distribution of demand, income and productivity in the CAM is governed by market power as well as by primary resource endowments. Regional trade agreements have the potential to accelerate growth in developing regions because aggregate demand effects can have a pronounced influence on productivity.

g) Global economic growth is limited by resource and environmental constraints. Nearly all blocs exhibit increased consumption of raw materials, especially energy. Since supply is limited by current investments, infrastructure and technology, periods of sustained economic growth can result in substantial price increases. The implications are that: (i) not all countries will completely abandon production of raw materials and energy because earnings will remain sufficiently attractive; and (ii) all countries can obtain further productivity gains by becoming more efficient in the use of energy and raw materials. In the long run, prices might decline because technology and patterns of consumption will change.

h) Currently, the CAM can take account, to a large degree, of constraints to growth and development highlighted in 'three-gap country models' (Bacha, 1990; Taylor, 1993). The model's global approach can clarify bottlenecks and allow resources to flow implicitly to poorer developing countries (see also Cripps and Godley, 1978). However, the critical problem 
of taking account of flows of global development finance, as highlighted in Vos (1994) and FitzGerald and Vos (1991), will remain unresolved until a modified CAM can incorporate financial stocks and flows as part of the model solution. For now, model solutions assume that international institutions could allocate financial entitlements, such as SDRs, and direct ODA from rich countries to poor countries in order to kick-start a pattern of accelerated growth, trade and development. ${ }^{3}$

i) The CAM approach differs from mainstream views not only in its handling of macroeconomic dynamics, but also in its scope. It does not present 'forecasts' but only 'scenarios'. It uses historical developments and stylized patterns that are embedded in existing macroeconomic structures in order to generate internally consistent and plausible scenarios that are based on the accumulation of assets and liabilities, changes in price structures and shocks. While the CAM can be used to critique forecasts of conventional models, more importantly, it can provide a framework to help 'think about' how current economic systems work and how they can be altered to advance human well-being.

\section{SCENARIOS FOR THE WORLD ECONOMY}

This section outlines three main global scenarios. The first describes the pattern of growth of the U.S. economy and the world economy that is assumed by U.S. policymakers and international financial institutions. The scenario incorporates this assumed pattern into the world trade and income model in order to generate the implied macroeconomic outcomes. The second scenario describes what we consider to be a more realistic outcome, namely, a significant slowdown in the U.S. economy and adverse consequences for the world economy. The third scenario proposes a more optimistic alternative that involves a correction of global imbalances and a sustainable acceleration of growth. But this scenario requires structural change and a significant degree of international policy coordination, particularly among developing countries.

\section{SCENARIO ONE: THE 'CONSENSUS GROWTH FORECAST'}

According to the official view in the U.S., the economy is expected to grow at 3.4 per cent during 2005-2009 and 3.2 per cent during 2010-2015. This projected rate is above the U.S. trend rate of growth during 1970-2005, i.e., 2.8 per cent (see Figure 1). Examining this projection with our world trade and income model, we conclude that under the present structure of the U.S. economy and the state of global imbalances, such a forecast is not realistic. The main contours of our analysis are outlined on Figure 1.

\section{The Impact on the External Sector}

Our first major point is that if the U.S. economy grew at the rate assumed above, the deterioration of the U.S. trade balance would accelerate. Using even conservative assumptions, our world model estimates that the trade balance would worsen from minus 6.3 per cent of GNP in 2005 to at least minus 8 per cent of GNP by 2015 (Figure 2). 
FIGURE 1

US Income Growth

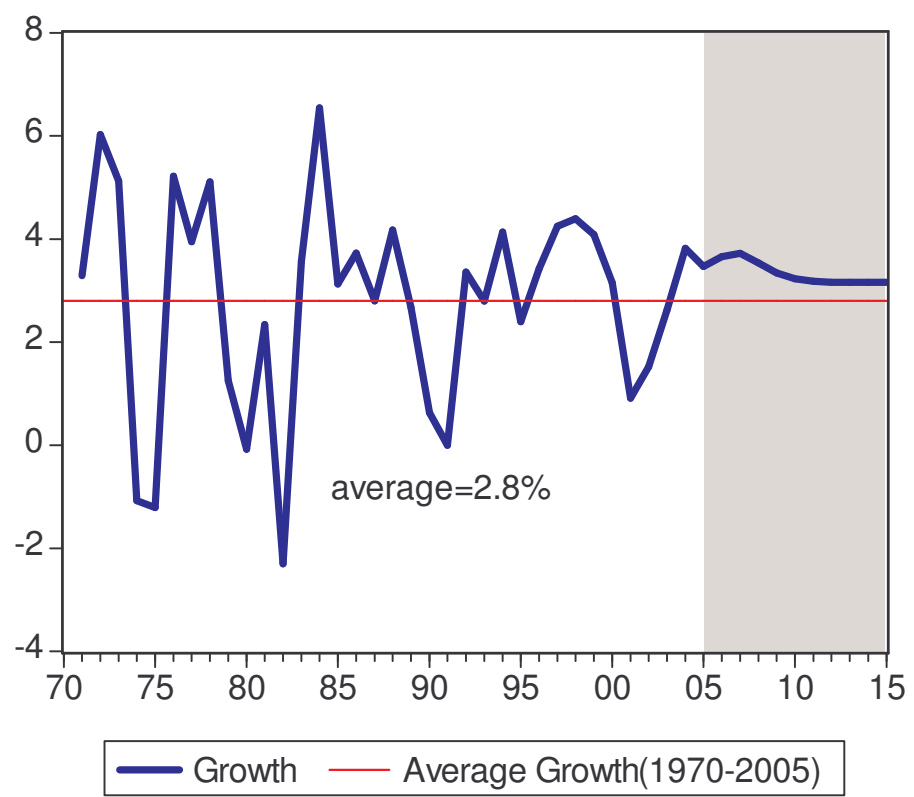

FIGURE 2

US Trade and Current Account Balances

(\% of GNP)

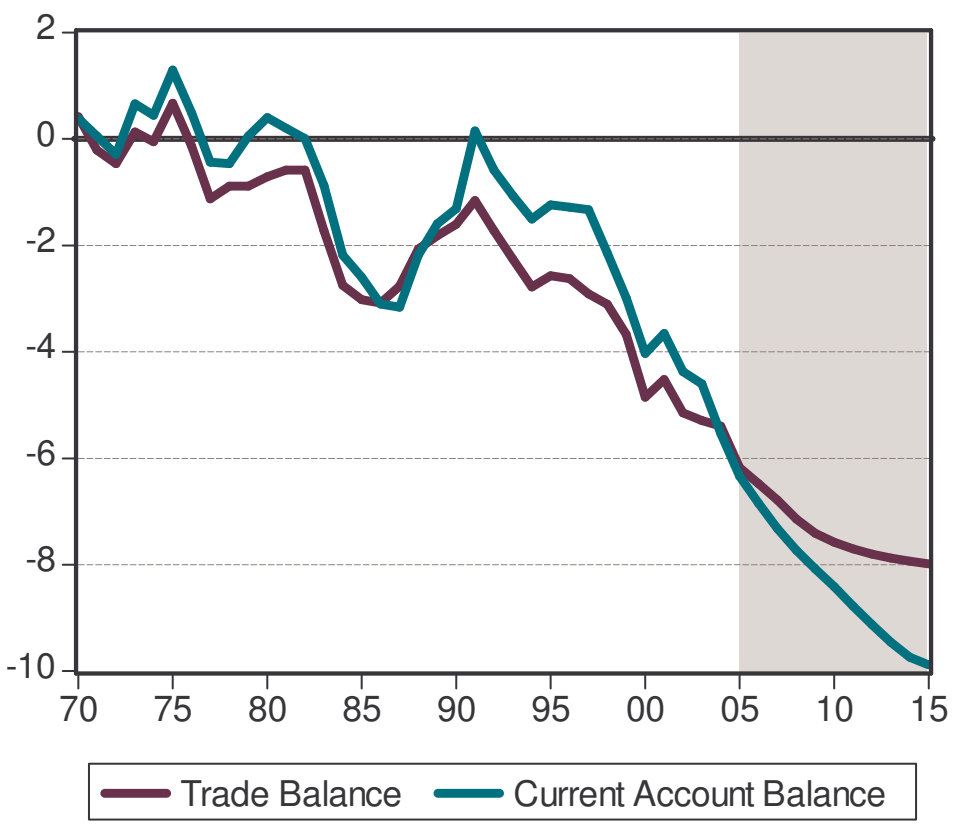


It is also evident that the U.S. current account balance would worsen even further. If the trade balance deteriorated in coming years, the net liability position of the United States would follow suit. Increases in the U.S.'s huge stock of debt would imply an increasing flow of factor payments abroad. Using moderate assumptions with regard to interest and dividend payments as well as remittances and transfers, we calculate that the current account would approach minus 10 per cent of GNP by 2015 (Figure 2).

The current net liability position of the United States represents about 30 per cent of its national income. ${ }^{4}$ If the current account deficit continues to rise as postulated, by 2010 the net debt of the U.S. to the rest of the world would increase to more than 50 per cent of its national income and by 2015 to more than 80 per cent (Figure 3). Much smaller levels of external debt have eroded the confidence of international investors in other countries. Eventually, the same is likely to happen to the U.S. economy.

FIGURE 3

Net Debt Position of the US vis-à-vis the Rest of the World, Historic and Projected Levels (\% of GNP)

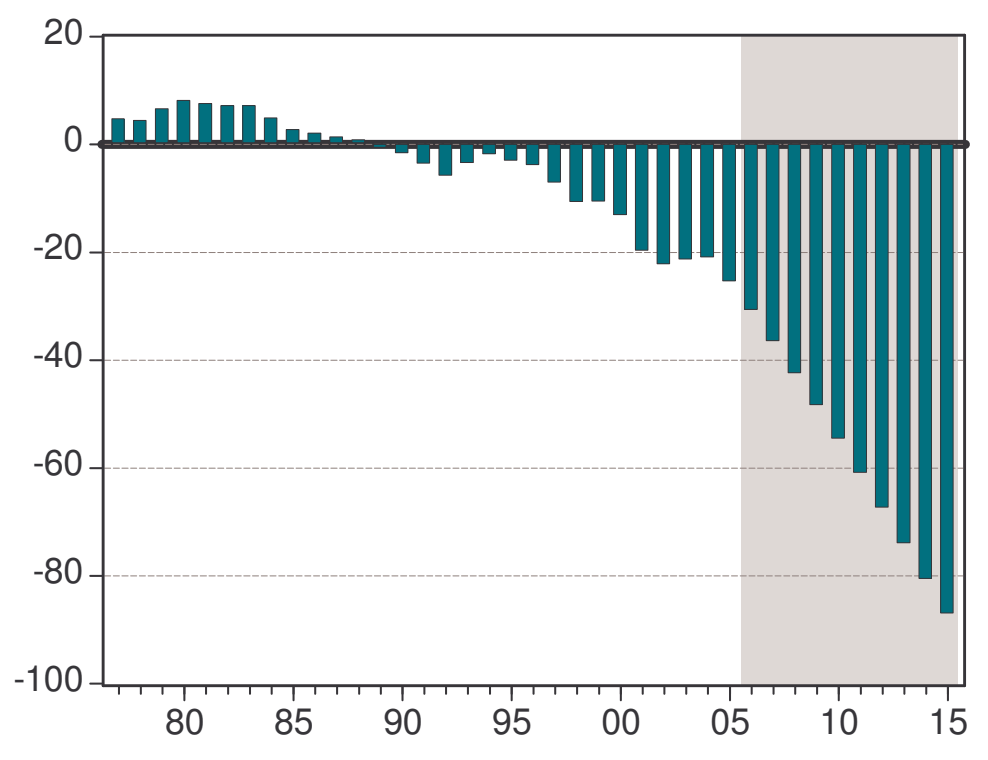

Many analysts of the U.S. economy remain complacent about its accumulation of external debt. They regard the continuance of net capital inflows into the U.S. as a sign of confidence of international investors. However, when non-residents acquire U.S. assets, there is a transfer of ownership abroad. For example, the total stock of foreigners' investments (official and private) in the equities and bonds of the U.S. corporate sector currently accounts for 37.5 per cent of the total value of corporate assets. ${ }^{5}$ Current trends would lead to foreign ownership of over 55 per cent of corporate America by 2015 (Figure 4). 
FIGURE 4

Stock of Foreigners' Financial Investment in the US Corporate Sector

(\% of Total Corporate Assets)

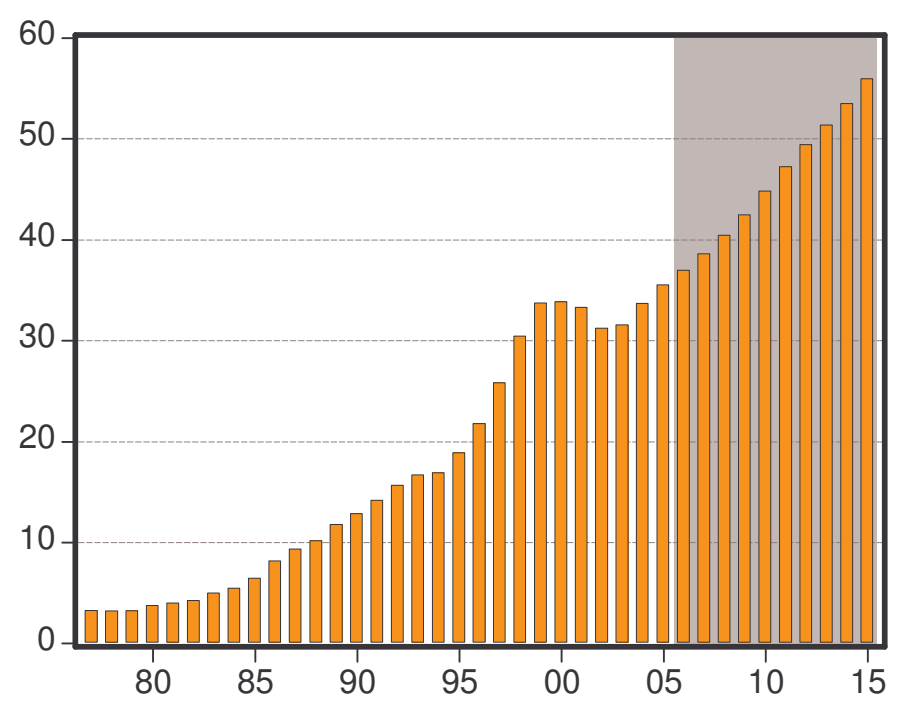

Similar trends would affect the ownership of U.S. Government securities. Foreign ownership is already approaching 70 per cent of the total value of government financial assets, and would peak at over 90 per cent in five years. ${ }^{6}$

\section{The Consequences for U.S. Domestic Sectors}

Because of the leakages of income out of the U.S. economy due to growing current account deficits, the consensus forecast of growth is plausible only if the domestic public sector or private sector add substantially more aggregate demand to the economy. But what are the implied macroeconomic conditions under which these sectors could perform such a function?

The financial balances of the external account, the private sector and the public sector are intrinsically linked with one another by accounting and macroeconomic logic. As recurrently explained by Wynne Godley in a series of publications (Godley 1995, 1996, 1999; Godley and Martin, 1999), if the current account balance is determined by the forces of growth at home and abroad, once the financial balance of one of the other two sectors is determined, the balance of the third unequivocally follows. These inter-relationships, which are strictly derived from the main macroeconomic identity that defines national income, are shown below:

$$
\text { 1) }(Y-T-E X P) \equiv(G-T)+(X-I M-N F P)
$$

where $(Y-T-E X P)$ is the private sector surplus (income minus taxes minus private expenditures); $(G-T)$ is the government deficit (expenditures minus taxes) and $(X-I M-N F P)$ is the current account surplus (exports minus imports minus net factor payments and transfers).

Though Equation 1 is an identity, the arrangement of the terms is intended to suggest the direction of causality that is assumed in the 'consensus forecast' (but which we will later critique). On the right-hand side we have two terms in parentheses. The government deficit 
$(G-T)$ is regarded as a policy-determined outcome, basically under the control of the government. The current account balance $(X-I M-N F P)$ is determined by assumed growth patterns in the U.S. economy and the world economy. Consequently, the value of the left-hand side, which shows private sector net savings ( $Y$-T-EXP), follows logically from the accounting identity, namely, from the values of the right-hand terms. As we will show below, this is not merely a corollary of national accounting; it abides by a macroeconomic logic as well. The role of the private sector has to become the main driver of spending for the U.S. economy. ${ }^{7}$

In Figure 5 below, the current account surplus, which was hovering around balance before the 1980s, turned negative in the 1980s, recovered in the late 1980s and early 1990s and then turned negative again as imports increasingly exceeded exports. In recent years, the current account deficit has reached unprecedented levels with respect to GNP. In line with Equation 1 above, the government sector is plotted as a deficit, i.e., as the 'public sector borrowing requirement' (points above the zero line denote that the government spends more than it receives in revenue). Historically, the public sector has been in deficit, with the exception of the last years of the Clinton administration. During the first three years of this century, the public sector moved sharply into deficit again. The official view posits, very optimistically, that the general government deficit will shrink in coming years and approach zero, as plotted in Figure $5 .^{8}$ This assumption places a heavy burden on other sectors to counteract such a contractionary trend.

Once the public sector borrowing requirement is assumed along with the current account deficit, the private surplus (or the net acquisition of financial assets by the U.S. private sector) is also determined. So, the third line plotted in Figure 5, namely, that for the private sector, shows a surplus before the late 1990s, and a deficit beginning in 1996. The decline of the private sector balance over the last decade and a half reflects the trend that total spending (consumption and residential investment) has been increasingly greater than disposable income (income minus taxes).

FIGURE 5

Net Saving Positions of the Main Sectors of the US Economy: Private, Public and External (\% of GNP)

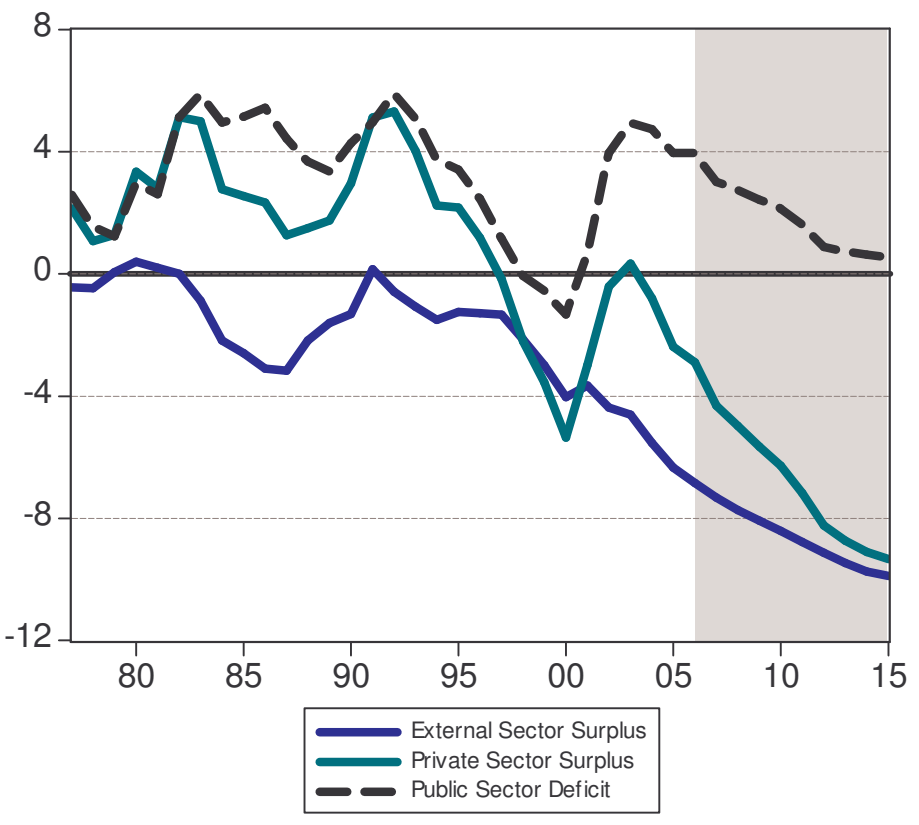


Figure 5 shows the current account deficit approaching minus 10 per cent of GDP in 2015, as previously reported. Since the public sector borrowing requirement is projected to approach zero by 2015, the private sector has to shoulder the resultant burden of compensating for the lack of aggregate demand. This implies that it has to spend dramatically more than it receives in income, and at an increasing rate. In other words, it has to become a much larger net borrower. Thus, the private sector deficit converges towards the level of the current account deficit by 2015. This has to be the case if the projected rate of economic growth of the 'Consensus Growth Forecast' is going to be attained.

In order to deepen the analysis, we disaggregate the private sector into businesses and households. The corporate sector has typically cycled between positions of small deficit (during economic expansions) and small surplus (during economic downturns). Currently, the financial balance of the corporate sector is showing an unprecedented surplus, caused in part by its adjustment after the financing squeeze that it experienced in the last recession and in part by its continuing reluctance to invest (see Figure 6).

We assume that, based on historical patterns, the corporate sector would add to aggregate demand in coming years. Its financial surplus would likely turn into a small deficit of about minus 0.5 per cent of GNP. ${ }^{9}$ By accounting logic, the net dis-savings of the personal sector must reach about ten per cent of GNP by 2015, as is shown in Figure 6. This is consistent, in macroeconomic accounting terms, with the projected trends in the current account and government budget.

FIGURE 6

\section{Net Private Savings Disaggregated: Personal and Corporate Sectors (\% of GNP)}

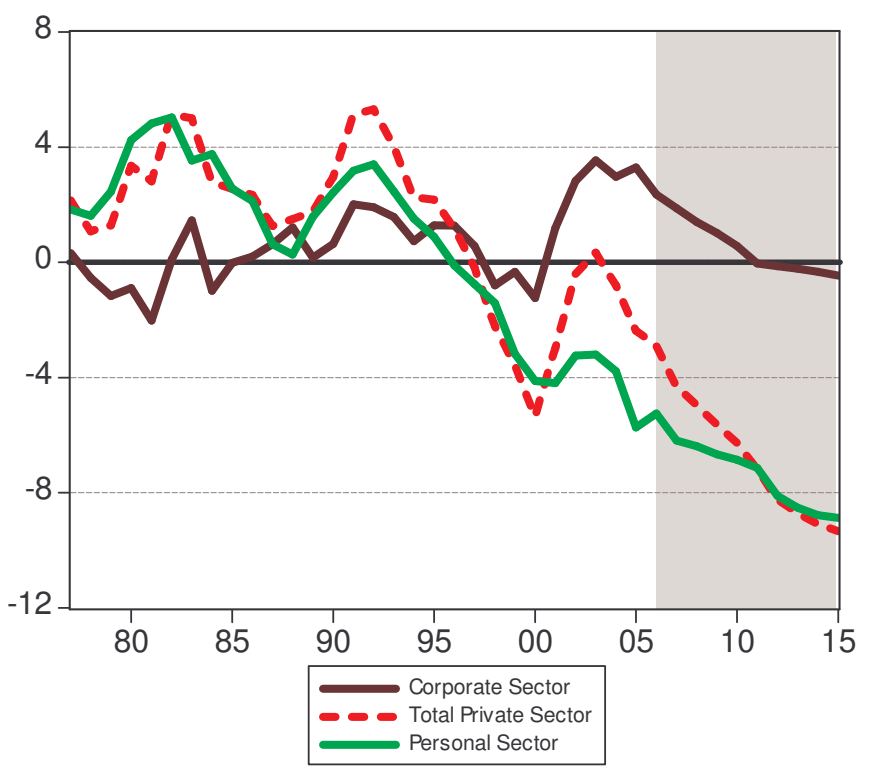

This consistency implies that given the assumptions of the future balances of the current account and the government budget, the U.S. economy can achieve the projected rate of growth only if the personal sector provides the additional aggregate demand (which it has already managed to do in the past). Indeed, since the early 1990s, the personal sector has been the main driver of U.S. aggregate demand. This is replicated in Figure 7, in which the net 
savings of the personal sector (disposable income minus total expenditures) became negative by 1997 and is projected to continue dropping through 2015. Figure 7 also shows that the trend for the personal sector converges with that of the current account. In other words, spending in excess of income by the personal sector is compensating for the drag on aggregate demand exerted by current account deficits (as the public sector balance approaches zero). The corollary of the current stress on achieving public-sector balance is a prescription for private-sector extravagance. We explore below what is required to sustain such private-sector profligacy.

\section{FIGURE 7}

\section{Financial Balances of the Personal Sector and the External Sector (\% of GNP)}

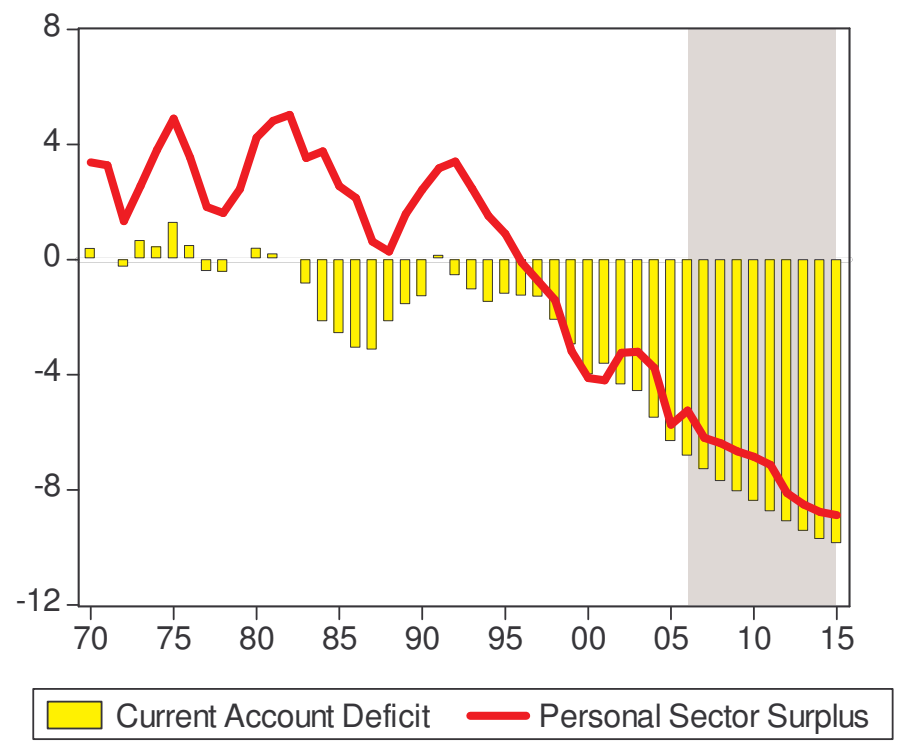

The decline of the personal sector's net savings could be possible only through either increases in its borrowing or erosion of its financial wealth. Personal sector borrowing has indeed already reached an unprecedented 16 per cent of personal disposable income. The continuance of this trend is required for fulfilling the consensus forecast of U.S. economic growth. Figure 8 shows that net savings and net borrowing of the personal sector are moving, as one would expect, in opposite directions. However, their movements do not exactly mirror each other because some variations in the stock of the sector's financial wealth is also occurring.

Since the personal sector has continued to borrow, its debt stock relative to disposable income has been accelerating since the start of the expansion in the 1990s, rising from 107 per cent of its income at that point to the current level of 155 per cent. If such spending and borrowing patterns continue, personal debt will rise further, to more than 250 per cent of income by 2015 (Figure 9). 
Figure 8

Net Saving and Borrowing of the Personal Sector (\% of Disposable Income)

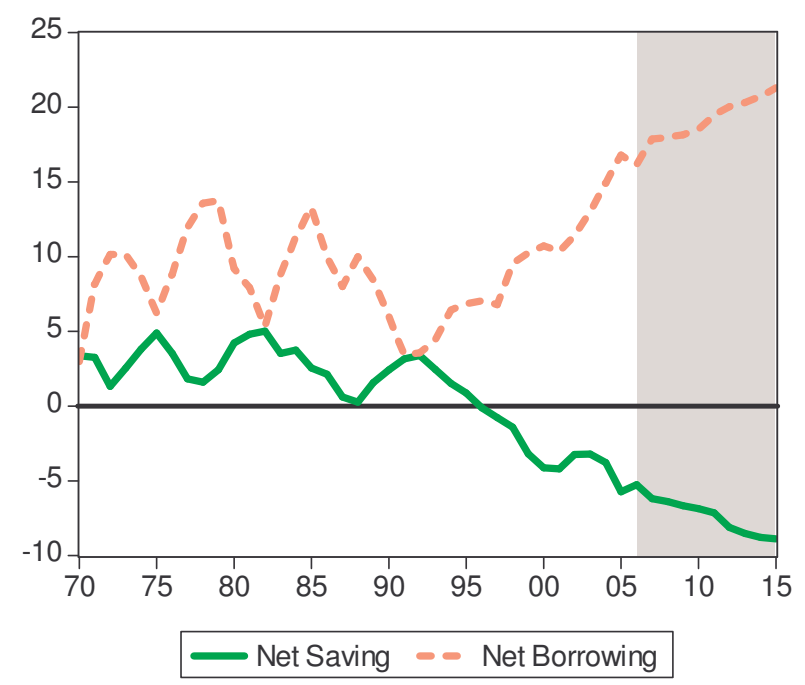

FIGURE 9

Debt Stock of the Personal Sector (\% of Disposable Income)

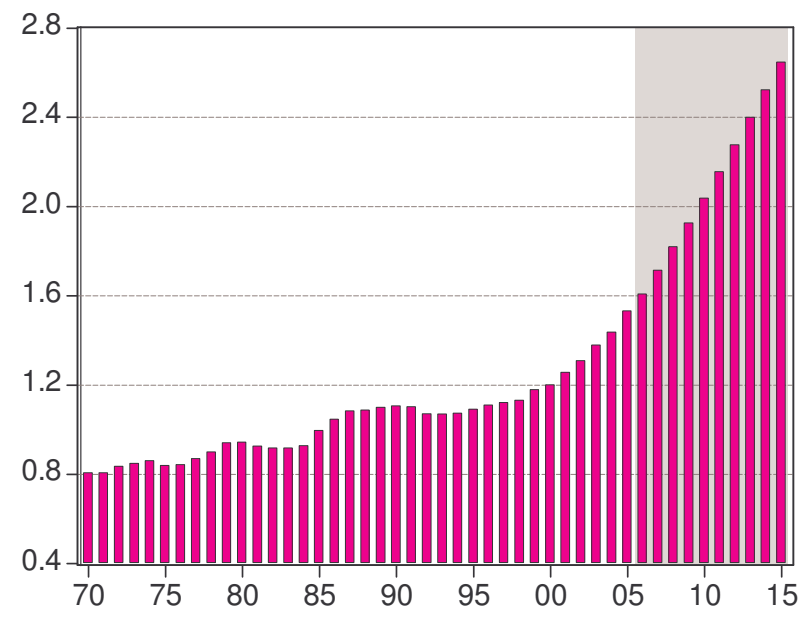

But why does the personal sector continue to borrow so heavily? And why does the financial sector continue to lend to it? The chief reason is that the personal sector's assets continue to appreciate. Also, low interest rates have helped contain the rise in its financial obligations. But low interest rates are not likely to continue in the future if the economy grows in accordance with the consensus forecast. Thus, for households to be prepared to shoulder higher levels of debt, the appreciation of their personal assets must continue to accelerate. The resultant increases in their net worth would enable them to continue borrowing.

More specifically, such a rising trend of personal-sector spending could continue only if a configuration of asset prices similar to the one pictured in Figure 10 persists. Such an appreciation would ensure that the net worth of the sector is not eroded as a result of the accumulation of debt. The values of shares in the U.S. stock market and the value of housing have to keep rising at a pace that is increasingly more rapid than the inflation rate. ${ }^{10}$ 
FIGURE 10

Asset Prices: Houses and Stocks (Indices in real terms using the GDP deflator)

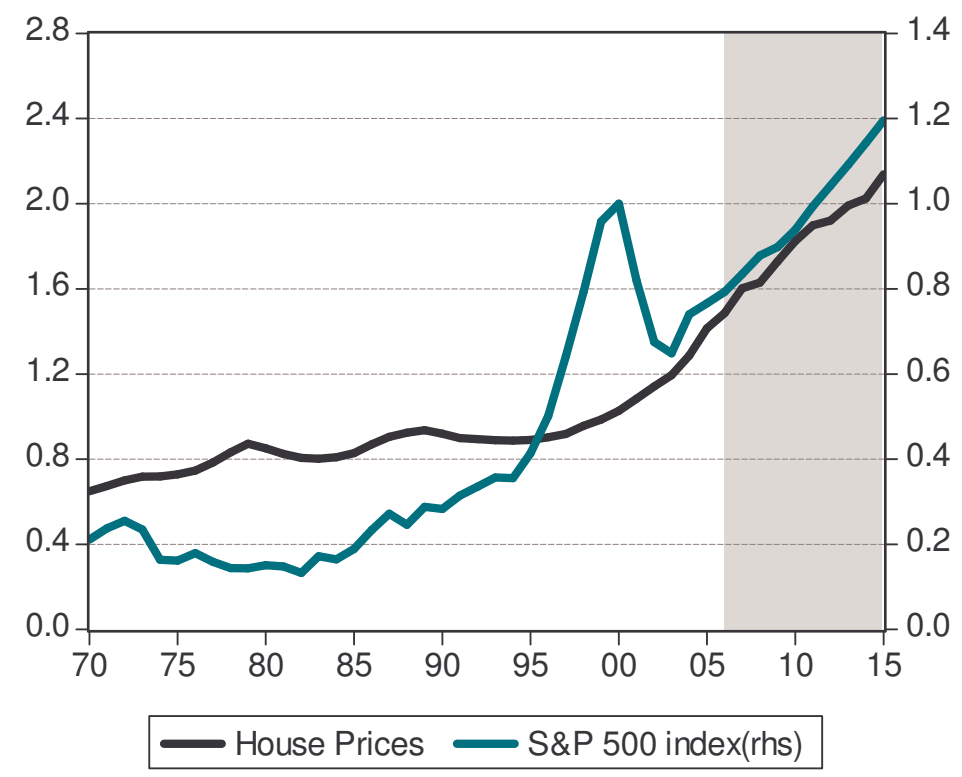

\section{The Limits of the 'Consensus Forecast'}

Above, we have dealt with the implications of the Consensus Growth Scenario for the U.S. economy's structure of aggregate demand, credit flows, financial liabilities and asset prices. These are not assumptions. They are logically derived consequences of the consensus view, taking the underlying dynamics and macroeconomic structure of the U.S. economy into account.

If policy changes do not occur to improve the external sector and fiscal deficits continue to shrink, the motor of the continuing expansion of the U.S. economy has to be the personal sector. As a result, the current account deficit will expand and the debt position of the U.S. will balloon to proportions similar to those experienced by many developing economies. However, contrary to historical experience, the prevailing expectation is that international investors will remain confident in the U.S. economy and U.S. residents will remain complacent about the implied transfer abroad of ownership of U.S. assets. Households are expected to continue spending when their level of debt becomes more than twice their income level, while the prices of their assets become only 50 per cent higher than their present level. As should be obvious, this entire set of projected conditions is highly improbable.

\section{The Impact of U.S. Growth on the World Economy}

What is the impact on the world economy of the consensus scenario for the U.S. economy? We turn now to this pivotal question.

The U.S. has been the main driver of global growth by generating unprecedented external deficits. These have translated into increasing demand for the exports of the Rest of the World. Along with the growth of the U.S., growth in major countries running large current account surpluses, such as China, has boosted global demand for energy and raw materials. This has created more demand for developing country exports of primary commodities. Figure 11 shows that the consensus scenario implies a growth rate in the Rest of the World that will approach eight per cent by 2015. 
FIGURE 11

U.S. and Rest-of-the-World Income Growth

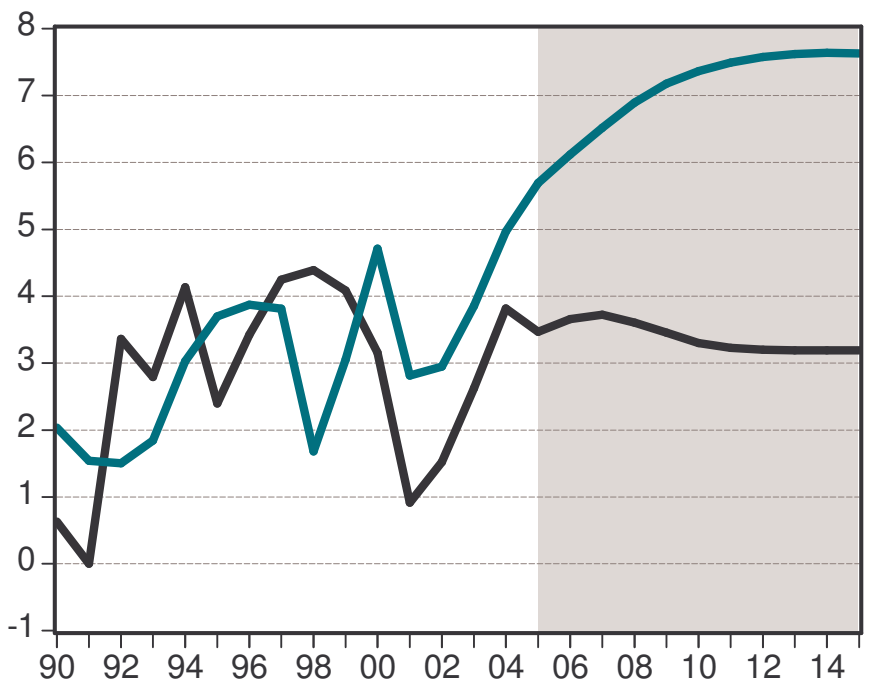

U.S. $\longrightarrow$ Rest of the World

Table 1 gives more details for the growth rates of various blocs and some major countries. Under prevailing assumptions and positing no structural or policy changes, such forecasts of growth rates are wildly optimistic. For example, Western Europe and Japan would experience a marked acceleration of growth. Japan's growth rate would increase to an average of 2.8 per cent during 2006-2015 from its one per cent rate during the last five years. While the developed world as a whole would grow at 3.5 per cent during 2006-2015, the developing world would grow at a much faster pace, namely, 10.0 per cent. This is about a two-thirds increase in the growth rate for developing countries, which grew at only 6.0 per cent during the last five years. Within the bloc of developing countries, China and the Middle East would grow most rapidly during 2006-2015, i.e., 10.8 per cent and 12.1 per cent respectively. Developing Asia (which excludes China) would grow more slowly, i.e., 10.5 per cent. Even Africa ${ }^{11}$ would grow relatively rapidly, at 9.0 per cent. Developing America would grow the slowest among developing regions, namely, 6.9 per cent (because of the levelling out of growth in the U.S. by 2015). 
TABLE 1

Income Growth in the Consensus Growth Scenario*

\begin{tabular}{lcccc}
\hline \multicolumn{5}{c}{ Consensus Growth } \\
\hline & $\mathbf{2 0 0 1 - 0 5}$ & $\mathbf{2 0 0 5}$ & $\mathbf{2 0 0 6 - 1 5}$ & $\mathbf{2 0 1 5}$ \\
\hline World & $\mathbf{3 . 7}$ & $\mathbf{5 . 0}$ & $\mathbf{6 . 7}$ & $\mathbf{7 . 2}$ \\
\hline Non U.S. (rest of the world) & $\mathbf{4 . 1}$ & $\mathbf{5 . 5}$ & $\mathbf{7 . 5}$ & $\mathbf{7 . 9}$ \\
\hline Developed & $\mathbf{2 . 0}$ & $\mathbf{2 . 5}$ & $\mathbf{3 . 5}$ & $\mathbf{3 . 5}$ \\
United States & $\mathbf{2 . 4}$ & $\mathbf{3 . 5}$ & $\mathbf{3 . 4}$ & $\mathbf{3 . 2}$ \\
Western Europe & 1.7 & 2.1 & 3.5 & 3.8 \\
Japan & 1.0 & 0.8 & 2.8 & 2.0 \\
Other Developed & 3.3 & 5.1 & 5.1 & 5.2 \\
\hline Eastern Europe & $\mathbf{3 . 1}$ & $\mathbf{3 . 9}$ & 5.0 & 5.8 \\
Former USSR & 3.8 & 10.7 & 9.0 & 8.7 \\
\hline Developing (D'ing) & 7.6 & $\mathbf{8 . 1}$ & $\mathbf{1 0 . 0}$ & $\mathbf{1 0 . 0}$ \\
D'ing Asia (exc.China) & $\mathbf{6 . 0}$ & 7.7 & 10.5 & 10.1 \\
China & 5.5 & 9.6 & 10.8 & 10.9 \\
D'ing America & 8.9 & 6.7 & 6.9 & 6.2 \\
D'ing Africa & 3.0 & 7.7 & 9.0 & 10.0 \\
Middle East & 5.2 & 12.1 & 13.3 \\
\hline
\end{tabular}

* Country blocs are fully described in the Appendix.

\section{Energy Constraints on Global Growth}

A critical problem with the pace of global growth projected by the consensus scenario is its neglect of the challenge posed by rising energy demand. The supplies of energy and other raw materials are very likely to impose a major binding constraint on global growth. Our model estimates that energy requirements in the next ten years will be formidable. ${ }^{12}$ The pace of growth of demand for energy is projected, for example, to follow a path similar to that plotted in Figure $12 .^{13}$

FIGURE 12

\section{Energy Demand (Average Rate of Growth over 10 Years for each Point)}

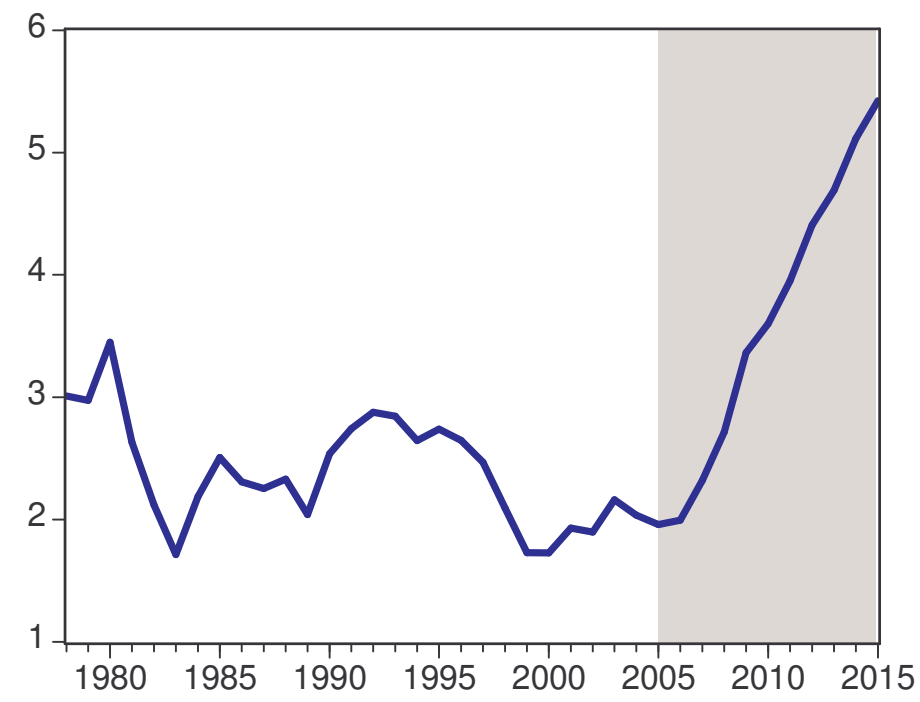


From 1995 to 2004, the average rate of growth of energy use was about two per cent (i.e., the point represented by 2004). However, we calculate that the consensus growth scenario for the global economy would entail an increase in the average growth rate of energy use during the next ten years to about 5.5 per cent rate (namely, over two and half times its previous average rate). But such a rate of growth of energy use has never been achieved - not even during the oil price spikes of the 1970s.

Even if it were possible to accommodate such growth in demand for energy, supply constraints would lead to a dramatic price escalation. Our forecasts are depicted in Figure 13. After 2005, the real prices of energy (deflated by the prices of manufactures) would begin to far exceed those prevailing during the two previous oil crises in the 1970 s.

FIGURE 13

\section{Energy Price Index (Deflated By the Price of Manufactures)}

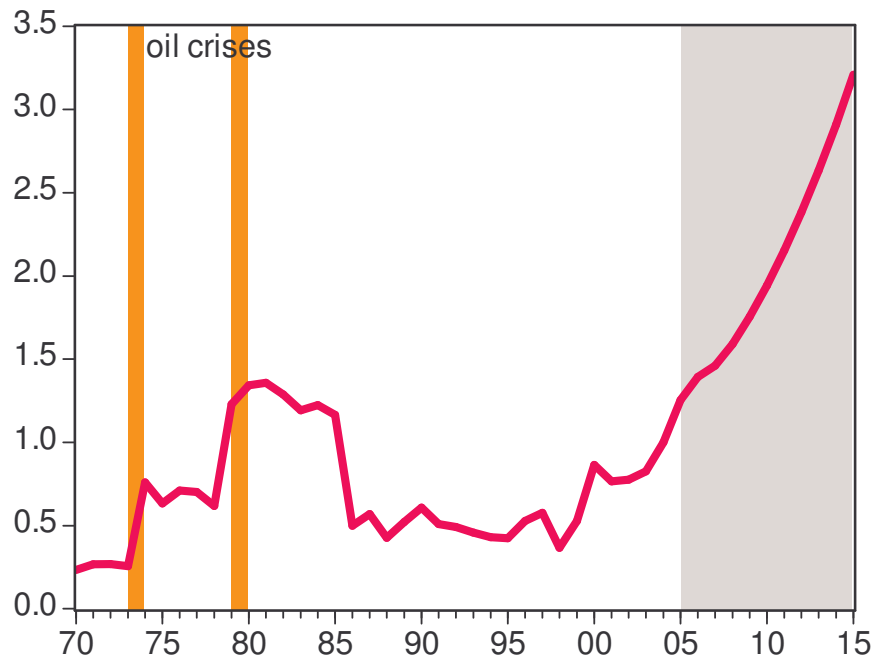

A similar constraint is likely to arise from the increasing demand for manufactured goods that is implied by the projected growth of global income. In order to loosen this constraint, several major changes would be required: more efficient use of raw materials and productivity increases that are due, in part, to greater diversification of production within regional blocs, and greater trade within and among those blocs. These improvements would lower costs and help mitigate macroeconomic imbalances within blocs and among them. Such advances would entail, however, major structural changes.

\section{Summing up: the Consensus Growth Scenario}

Is the rate of global growth implied by the consensus scenario plausible? For the various reasons detailed above, we believe that such a rate is highly improbable.

The rise in demand for energy and the escalation in its price represent only one binding constraint on global growth. Similar constraints would be imposed by the supply of raw materials and the production of manufactures.

The size of the U.S. current account deficit (i.e., reaching US\$900 billion in the last quarter of 2005) is absolutely unprecedented. The worsening of the net liability position of the United 
States vis-à-vis the Rest of the World would only intensify this deficit. Eventually, the confidence of foreign investors in the U.S. economy would be eroded. The personal sector in the United States would have to shoulder the onerous burden of providing the chief spending stimulus to the economy. Unfortunately, it could do so only by continuing to indulge in a spree of borrowing and debt accumulation - at a level far in excess of any historical average.

The projected trends would become increasingly vulnerable to changes in the value of assets, exchange rates, interest rates, and prices (especially of raw materials and energy). The overall dynamic would be much more prone to an abrupt halt than to a sustained period of expansion. The likeliest outcome would be a sudden rupture in personal-sector spending based on the exhaustion of personal borrowing. A slowdown in asset appreciation could be the decisive trigger, exacerbated by a rise in interest rates needed to stem capital outflows. As a result, the U.S. would slide into recession.

The onset and the pace of economic decline are difficult to predict. However, the direction and the orders of magnitude appear clear. We now outline the likeliest scenario if no major policy changes and no structural reforms of the world economy are undertaken. Further below in the third scenario, we will present general recommendations on how such a dire scenario could be avoided and how a more mutually beneficial outcome for various blocs of countries, especially for developing countries, could be achieved.

\section{SCENARIO TWO: A SEVERE SLOWDOWN IN THE U.S. ECONOMY}

A break in the current pattern of global growth triggered initially by a slowdown of household spending in the United States is a plausible outcome of current world macroeconomic imbalances if no countervailing policies are undertaken. This scenario should not be regarded as a forecast but as a logically derived adjustment based on the observed structural patterns of U.S. aggregate demand and debt financing. Central to this dynamic are 1) predictable stock-flow relations between spending, saving and wealth accumulation and 2) the probable consequences of the underlying borrowing behaviour of households and other economic units.

\section{Stock-flow Relations and 'Speculative Confidence'}

In modern capitalist economies, spending follows a pattern in which households, in the aggregate, direct a certain proportion of their income to the accumulation of financial wealth. Their desired, or 'target', stock of wealth, properly measured, tends to have a stable relationship with income (see Godley \& Cripps, 1983).

The reason is that such a target stock, valued in the future, is expected to generate a stream of income roughly in line with current conditions. But the way in which agents, in the aggregate, 'measure' their financial wealth is an act of 'speculative confidence' about its future value (see Box 1). Since, under normal circumstances, agents do not really know about future conditions, they follow a 'convention' by which they project the current state of affairs over a longer term.

Thus, when both the growth of income and the growth of the value of financial assets follow a predictable pattern, the ratio of accumulated financial wealth to income would remain stable. However, if for a certain period the value of financial assets rises at a pace considerably faster than income, agents in the aggregate would assume that they are accumulating 'more 
wealth' than they expected for the future. As a result, they would start to save less. This appears to be the underlying behavioural response of the household sector in the U.S. after the expansion of the 1990s started. The stock market was booming and the value of accumulated financial wealth was growing.

Such a process of dis-saving cannot continue indefinitely, however. There are two major reasons. One reason, which relates to asset prices and stock-flow norms, is discussed here. The second complementary reason, which relates to borrowing behaviour, is analysed in the next section.

Only if asset prices in the U.S. continued to accelerate would households in the aggregate feel confirmed in their 'convention' that the value of already accumulated financial wealth is too high, compared with income, and would thus be motivated to dis-save. The required path of asset appreciation needed to elicit this behaviour is plotted in Figure 10. Since it is highly unlikely that asset prices will continue following such a path, the value of personal-sector wealth would not increase as expected. In response, households would begin to save, rather than adding to aggregate demand by spending at their current rate.

To what degree has the accumulation of financial wealth fallen with respect to income? An approximation can be obtained by plotting the ratio of wealth to income over time, 'controlling' for the effect of asset prices. Figure 14 shows the ratio of wealth to income of the household sector. Nominal wealth is adjusted by a (weighted) index of asset prices while nominal income is adjusted by a price index of goods and services. Thus, both the numerator and the denominator are converted into 'volume' indicators.

Over the 20-year period of 1976-1995, the personal sector roughly preserved a stable stock of real financial wealth relative to real income. This ratio was about 1.4. Starting in 1996, however, it began to fall sharply. The ratio rebounded with the onset of the shallow recession in 2001 because households partially restored their savings in response to the substantial loss of financial wealth associated with the stock market crash. However, as is evident in Figure 14, this adjustment has been incomplete since the ratio has stagnated at a low level of around one after 2003. Though the plot in Figure 14 is admittedly an imperfect representation of the underlying financial behaviour of the personal sector, it is nonetheless a persuasive confirmation that current spending patterns are indeed precarious.

If we assume that the historic norm is represented by the period 1976-1995, when asset prices were broadly in line with what standard measures, such as the price-earnings ratio and Tobin's q, would predict, the household sector should feel compelled to restore wealth, through increasing their real savings, by about 40 per cent of their income. The implied weakening of aggregate demand, absent other changes, would precipitate a severe recession. 
FIGURE 14

Real financial wealth of the personal sector relative to income

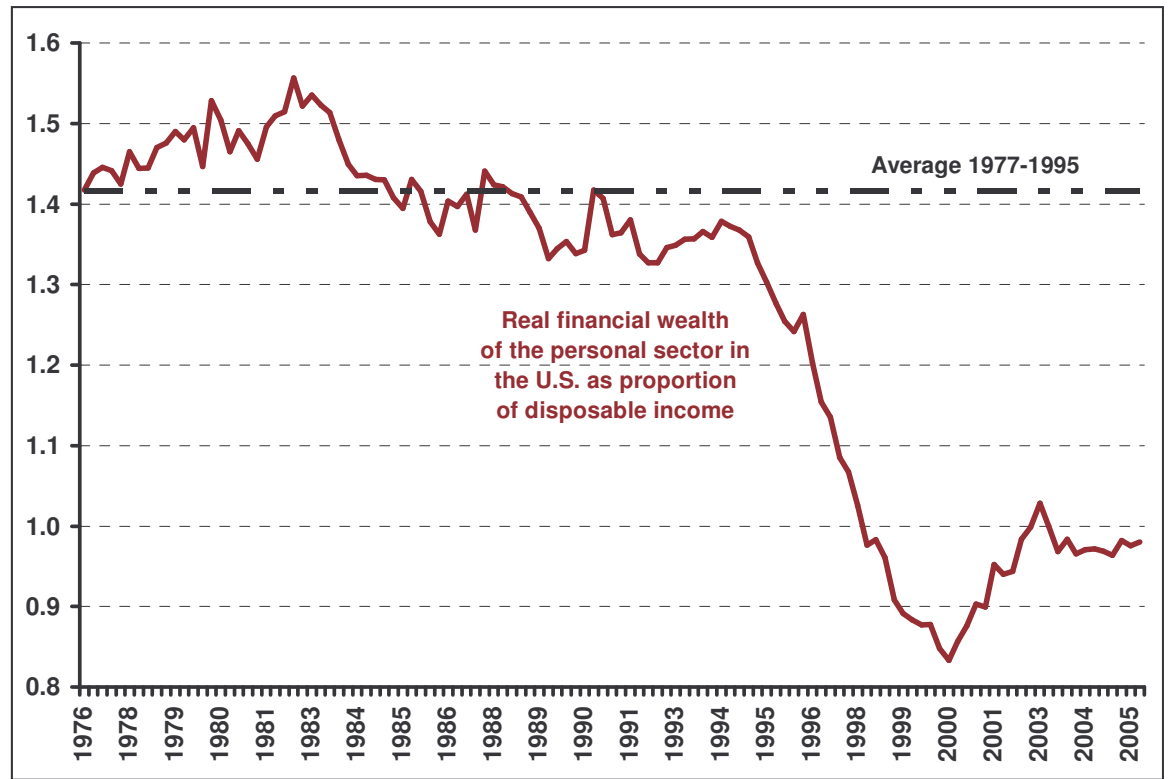

\section{Borrowing and 'the State of Credit'}

Spending beyond income is made possible by borrowing and the concomitant accumulation of debt. The stock of debt, because it ought to be serviced out of income flows in the future, should maintain a relatively stable relationship with prospective income. Figure 9 , presented earlier, showed that in 2005 the stock of debt of the personal sector was 50 per cent above its level of disposable income.

Figure 15 below shows that debt in real terms has been growing, during the last ten years, at an average rate of seven per cent per year, twice as fast as the average growth of real income (3.5 per cent on average). The figure shows that this gap in growth rates is markedly widening. In other words, had households started to fear at any time that they lacked the ability to service their current debt burden out of prospective income, either they would have sought to increase their real income by another three and a half per cent rate (i.e., reaching a yearly rate of seven per cent) or they would have reduced their spending by 3.5 per cent per year. These options would have re-aligned the debt stock with income flows. 
FIGURE 15

Ten-year average growth rates of debt accumulation and disposable income

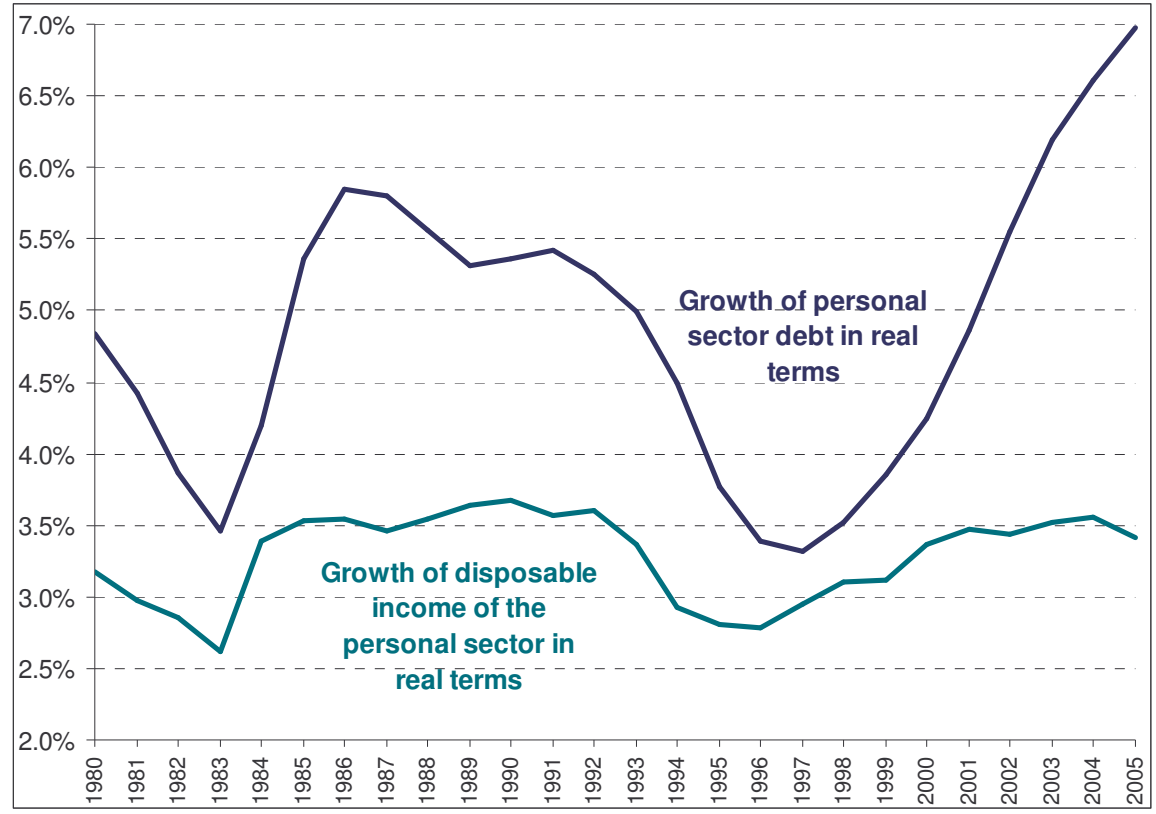

Meeting these conditions would have implied that the debt to income ratio stayed at its current, but still unprecedentedly high, level. However, a sustained seven per cent yearly rate of growth of real disposable income has never been achieved. The highest recorded average rate over any ten-year period for the United States was 6.25 per cent per year just before the first oil crisis in 1973. Since then, this rate has oscillated around 3.5 per cent. The inevitable conclusion of this analysis is that as soon as households have serious doubts about their ability to manage their debt burdens, they would begin lowering their spending levels. This effect would very likely precipitate a dramatic economic downturn since no other major sources for stimulating aggregate demand would be readily available. A substantial outflow of capital, prompted, for example, by continuing depreciation of the U.S. dollar would only intensify the downturn. Keynes masterfully analyzed the internal dynamics of such an adjustment long ago (see Box 1).

We turn now to describe patterns that the U.S. economy and world economy would likely follow if the predicted adjustment of domestic spending in the U.S. takes place, either by households own re-adjustments or by a lack of confidence of investors and an ensuing tightening of credit.

The likeliest outcome, according to our world trade and income model, would be an economic downturn. Table 2 below outlines how the economic downturn would affect various groupings of countries. These results, which are logically consistent from a global macroeconomic point of view, serve to highlight the overall configuration and direction of changes; they are not meant as predictions about the magnitude of the downturn and its timing. We assume 'optimistically' that growth of the U.S. economy would slow progressively over the next decade and reach negative rates only after 2012. 
BOX 1

\section{J. M. Keynes: speculative confidence and the state of credit}

The processes of wealth and debt accumulation in developed financial markets have been examined by many economists. Pioneering insights are found in Keynes' General Theory of Employment, Interest and Money. Keynes noted that the confidence that motivates agents to invest and build up wealth (what he called 'speculative confidence') and to engage in the accumulation of debt (what he called the 'state of credit') can remain high so long as the economic cycle is on the upswing, so that "much of the new investment shows a not unsatisfactory current yield". He remarked that such confidence seems an "almost essential condition of a satisfactory propensity to consume" (GT, pp. 319), which is the basis for propelling the demand multiplier. According to him, rather than being based on precise knowledge, such a state of generalized belief in the future is a convention. As he states, "the essence of this convention lies in assuming that the existing state of affairs will continue indefinitely, except in so far as we have specific reasons to expect a change" (idem, pp. 152).

These propositions roughly reflect the current situation in the U.S. economy and the world economy. As argued above, they also point to plausible factors that can change behaviour. As soon as economic agents start to perceive either that their acquired wealth might suddenly lose value with respect to income or that paying back their debt out of prospective income might not be tenable, their confidence is likely to quickly evaporate.

In his 'notes on the trade cycle', Keynes argues that "once doubt begins, it spreads rapidly". A collapse, which often takes place suddenly and violently, is not necessarily followed by a correspondingly sharp upswing. More importantly perhaps, "whereas the weakening either of speculative confidence or of the state of credit is enough to cause a collapse, recovery requires the revival of both" (idem, pp. 158). In sum, if a slowdown takes place, it will likely last for as long as the conditions are lacking for a revival of confidence and the expansion of credit.

The United States would be, in any case, the hardest hit: a moderate slowdown would translate into a loss of income potential from its yearly growth rate of 3.5 per cent in 2005 to a minus 0.6 per cent rate in 2015 . Figure 16 charts the drop in U.S. economic growth relative to its average performance during the period 1970-2004 (i.e., 2.8 per cent).

The drop in U.S. economic growth drives the rest of the results derived from our world model. Developed countries as a whole are projected to experience a fall in growth from 2.5 per cent in 2005 to -0.7 per cent in 2015. Developing countries would not experience recession: their growth would deteriorate from 8.1 per cent in 2005 to 4.5 per cent in 2015. These results are driven mainly by the recent growth momentum in Asia, Africa and the Middle East, either as exporters of manufactures or primary commodities (such as oil). China's growth rate would decline from 9.6 per cent to 5.8 per cent over ten years-i.e., a 40 per cent drop in growth rate. The relative slowdown in Developing Asia (excluding China) would be less pronounced, i.e., 29 per cent. Developing Africa (excluding South Africa) and the Middle East would be hit harder than Asia: their drop in growth rate would be around 50 per cent. However, the hardest hit would be Developing America, whose growth rate would decline from 6.7 per cent in 2005 to close to zero in 2015. 
FIGURE 16

\section{Growth of US Income}

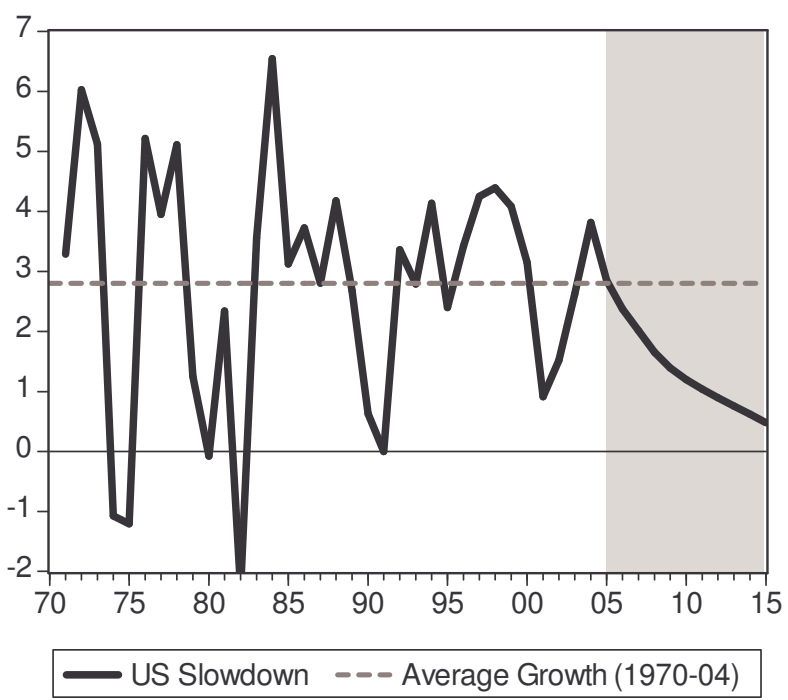

TABLE 2

\section{Income Growth in the Scenario of US Economic Slowdown}

\begin{tabular}{|c|c|c|c|c|}
\hline \multicolumn{5}{|c|}{ U.S. Slowdown } \\
\hline & 2001-05 & 2005 & $2006-15$ & 2015 \\
\hline World & 3.7 & 5.0 & 3.5 & 2.1 \\
\hline Non U.S. (rest of the world) & 4.1 & 5.5 & 4.2 & 2.7 \\
\hline Developed & 2.0 & 2.5 & 0.8 & -0.7 \\
\hline United States & 2.4 & 3.5 & 0.6 & -0.6 \\
\hline Western Europe & 1.7 & 2.1 & 0.8 & -0.7 \\
\hline Japan & 1.0 & 0.8 & 0.4 & -1.8 \\
\hline Other Developed & 3.3 & 5.1 & 1.8 & 0.4 \\
\hline Eastern Europe & 3.8 & 3.9 & 2.0 & 0.1 \\
\hline Former USSR & 7.6 & 10.7 & 5.1 & 2.7 \\
\hline Developing (D'ing) & 6.0 & 8.1 & 6.4 & 4.5 \\
\hline D'ing Asia (exc.China) & 5.5 & 7.7 & 7.4 & 5.5 \\
\hline China & 8.9 & 9.6 & 7.7 & 5.8 \\
\hline D'ing America & 3.0 & 6.7 & 2.9 & 0.1 \\
\hline D'ing Africa & 5.2 & 7.7 & 5.2 & 4.1 \\
\hline Middle East & 6.0 & 7.2 & 4.9 & 3.4 \\
\hline
\end{tabular}

If there were a sustained decline of growth in the United States, a recovery of its trade balance would result. This projected rebound is depicted in Figure 17. Unfortunately, this recovery would be based on dramatically adverse trends: a sharp drop in income, rising unemployment, a decline in household spending, tightening of credit, a decline in government revenue and an erosion of wealth. Moreover, this recessionary slide would likely be triggered, in part, by the rising prices of oil and other raw materials and accompanied by the depreciation of the U.S. dollar. 
FIGURE 17

US Trade Balance during Slowdown (\% of Income)

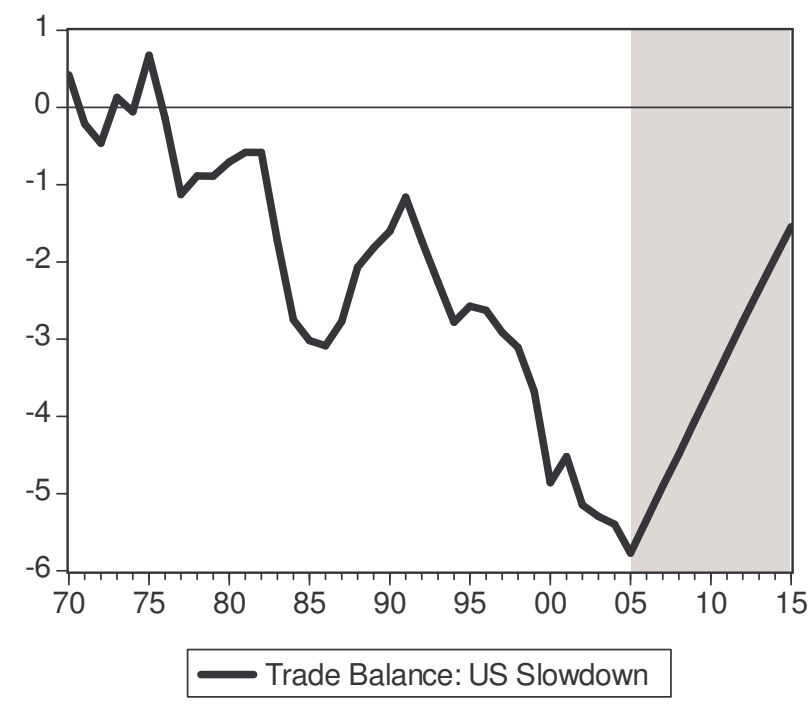

FIGURE 18

\section{Trade Balances}

(\% of each bloc's GNP)

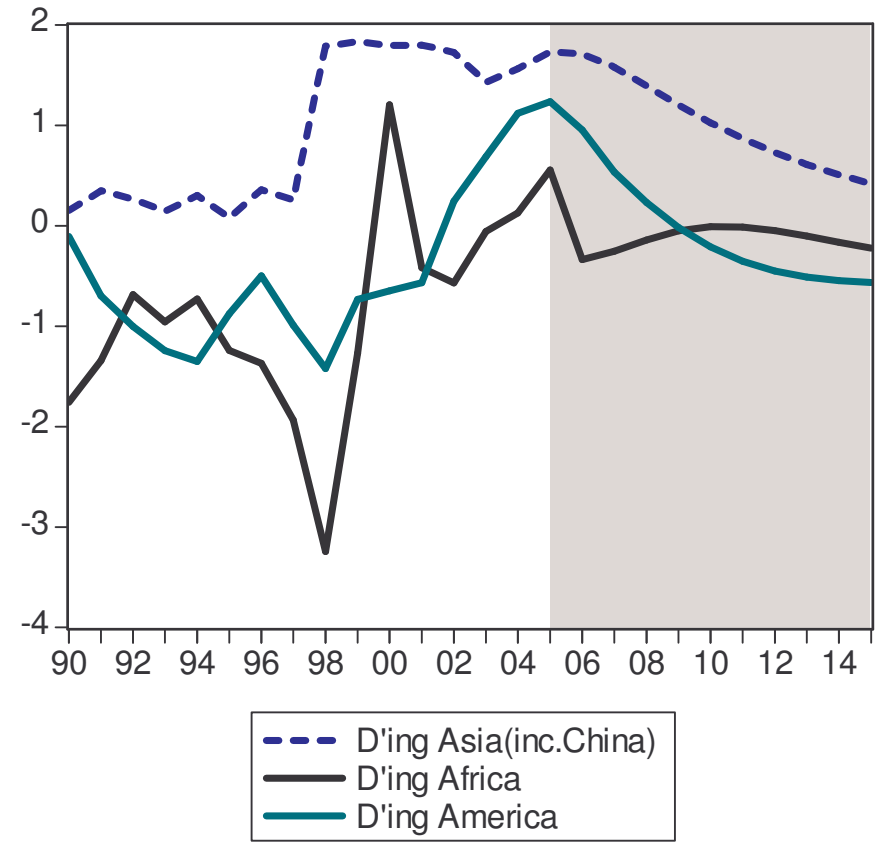

As the U.S. current account deficit would narrow, the surpluses of some of its major trading partners would be reduced. This would have serious implications, in turn, for developing countries that have been supplying oil and raw materials to these export-oriented 'surplus' countries. Figures 18 and 19 show the projected patterns of the United States trade deficit and the trade balances of other regions. In Figure 18 the trade surplus of Asia (including China) declines while the recent trade surplus of Developing America drops into deficit. The 
trade balance of Africa hovers around zero, after having dropped from a modest surplus. Figure 19 shows that the trade balance of Western Europe stays close to zero. However, Japan's trade surplus remains high, at over five per cent of its GNP. As in the U.S., the decisive factor for Japan would be a weakening of import demand, due to recession, rather than an improvement of export performance.

FIGURE 19

\section{Trade Balances}

(\% of each bloc's GNP)

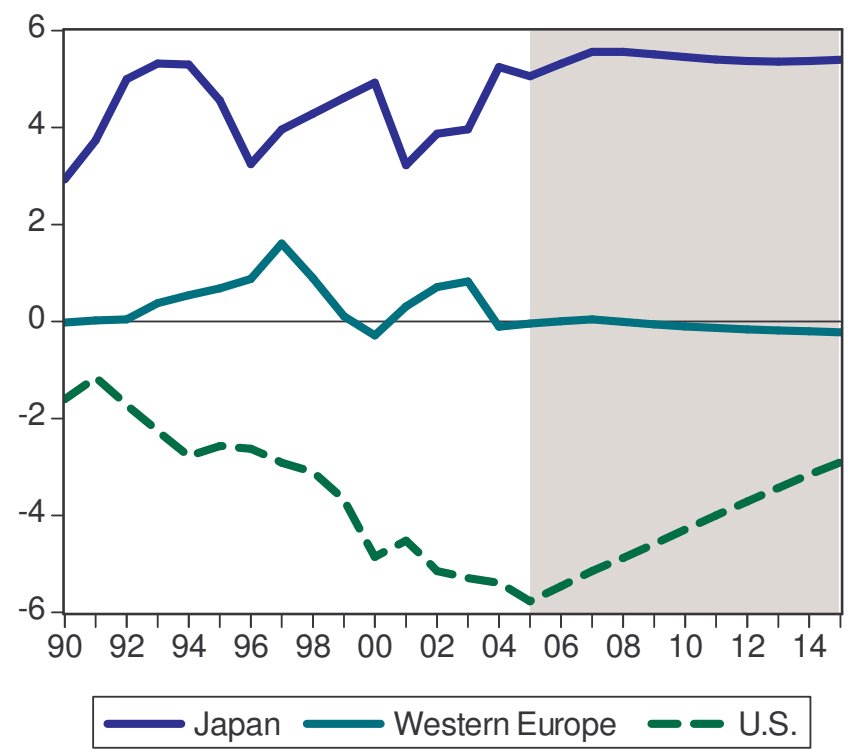

The Rest of the World (RoW) would clearly be affected by the U.S. slowdown during the next ten-year period. Its rate of growth would plummet from 5.5 per cent to 2.7 per cent, held up mainly by the performance of developing countries. Figure 20 shows the projected sharp drop in RoW income growth compared to its trend of recent years. This outcome would be accompanied by rising unemployment and underemployment, intensifying insecurity and increasing poverty.

The relative losses incurred by other regions of the world would vary depending on their trade links with the United States. Figures 21 and 22 are constructed to show relative losses by setting each region's or country's outcome against the growth that would have taken place in the absence of such a shock. Figure 21, which focuses on developing regions, shows that Asia (including China) would fare moderately better than the United States. However, while Developing Africa would fare better during 2005-2010, it would end up faring worse than the United States during 2010-2015. Compared to other developing regions, Developing America would fare the worst, losing more than 15 per cent of its potential income (compared to the outcome from its baseline growth).

Figure 22 shows that both Japan and Western Europe would fare better than the United States when each is compared with its own baseline trend. Japan would lose about nine per cent of its potential income while Western Europe would lose over 10 per cent. However, the category of Other Developed countries, which includes countries such as Australia, Canada and New Zealand, would lose the most in relative terms. 
FIGURE 20

ROW Income Growth with US Slowdown

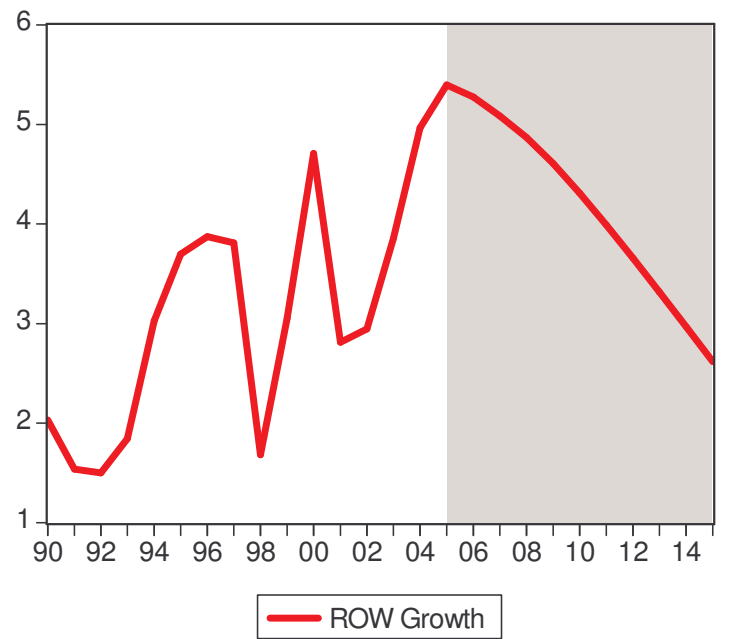

FIGURE 21

Income Loss for Developing Countries (\% of potential output if no shock occurred)

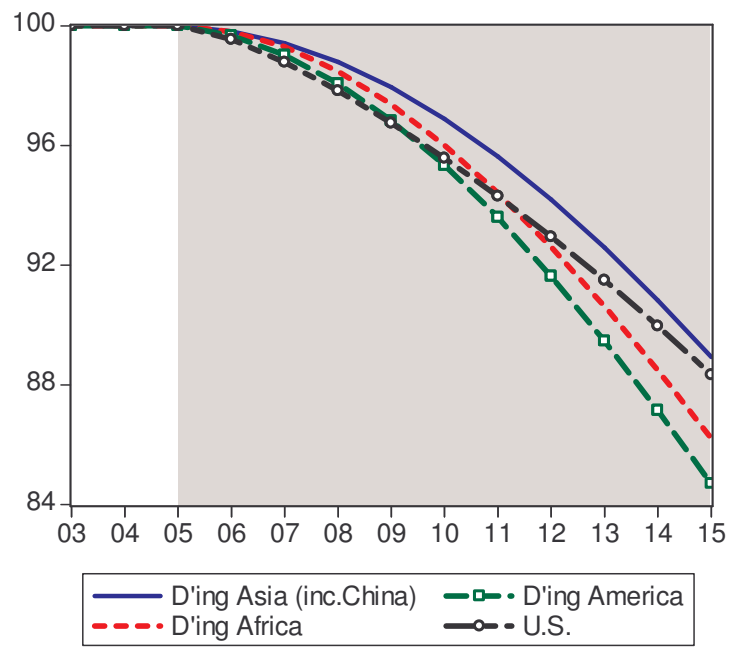

FIGURE 22

Income Loss for Developed Countries (\% of potential output if no shock occurred)

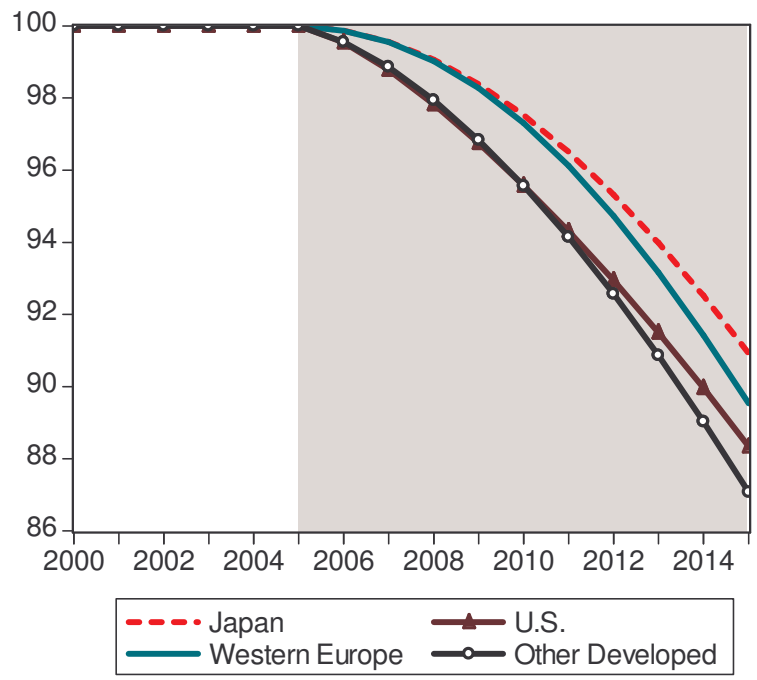


Once this dynamic of a U.S. economic slowdown starts and spreads its influence to other developed and developing countries, there are no endogenous, market-driven mechanisms that would prompt a near-term recovery. Hence, a global slowdown would likely persist until policymakers reacted forcefully with counter-cyclical interventions.

Keynes recognized that policy interventions are necessary in order to forestall or counteract recessions triggered by the depression of 'animal spirits'. As he states, "in conditions of laissez-faire the avoidance of wide fluctuations in employment may, therefore, prove impossible without a far-reaching change in the psychology of investment markets such as there is no reason to expect. I conclude that the duty of ordering the current volume of investment cannot safely be left in private hands" (Keynes, GT, pp.319). In relation to the current conjuncture, are there feasible policy options at the national, regional and global levels that could better 'order the current volume of investment' so as to avoid recessionary conditions and achieve sustainable growth?

\section{SCENARIO THREE: COORDINATED REFLATION AND STRUCTURAL CHANGE}

We now outline a third scenario that can help overcome the current global macroeconomic imbalances and substantially improve the prospects for more rapid global growth. We call it a co-ordinated, policy-driven growth scenario because it does not rely principally on market forces, as is the case with the Consensus Growth Scenario. This third scenario is 'technically' feasible. However, it will require a significant degree of policy coordination across countries, both regionally and globally.

The Coordinated Growth Scenario is based on 1) more expansionary macroeconomic policies in major surplus countries (particularly developed countries) and in poor deficit countries 2) increased investments in growth-enhancing manufacturing capacities in developing countries and 3) greater trade integration among developing countries (which would emulate the trend of integration already underway in Asia). The success of this scenario would also hinge on the implementation of concerted measures to promote energy savings and environmental protection.

This scenario embodies a re-arrangement of the global growth pattern. While all countries would benefit, developing countries would benefit disproportionately. The basic approach of this strategic policy package is to foster a global environment in which low-income developing countries can achieve 'catch-up' rates of economic growth through diversifying their economies and engaging in mutually beneficial regional economic integration.

Structural breaks in both trade and investment patterns are intrinsic to this scenario. Countries with large current account surpluses_-particularly those that have already accumulated sizeable foreign-exchange reserves-should be able to increase domestic absorption without compromising growth or economic stability. This would help stimulate growth in their economies and, by means of their increased import demands, growth in other countries as well. While developed countries with substantial current account deficits might experience a more moderate growth of domestic spending, their income growth over the medium term would likely be stimulated by increased demand for their exports due to growth in other countries. Although not explicitly modelled, an increase in capital flows to low-income countries is assumed as part of their success in diversifying their economies, exporting more manufactures and growing more rapidly. 
At this juncture, a clarification of the inherent macroeconomic logic underlying this simulation could be helpful. Adjustments in the world model are demand-driven: it is the structure of demand that generates income growth. Components of global demand (such as each bloc's absorption) are, in turn, dependent on global income, replicating global multiplier dynamics within the closed system of the world economy. In this context, typical simulations consist of 'injections', such as investment, which will have a multiplier impact on income. Moreover, if we think of income as a 'target', the task is to find the exact size of the injection ('instrument') that will achieve the 'target' income level. This approximates the 'targetinstrument' system devised by Tinbergen and is inherent in the Alphametrics model. In constructing this scenario, we have set a number of 'targets': income growth for most regions, energy demand, and balances of raw materials and energy. The primary instruments are domestic absorption and prices.

Figure 23 depicts the increase in the growth of global income projected by the Coordinated Growth Scenario as well as growth trends since 1980. As it shows, global growth reaches 7.4 per cent by 2015, rising from 5.0 per cent in 2005.

FIGURE 23

\section{Global Income Growth with Coordinated Growth}

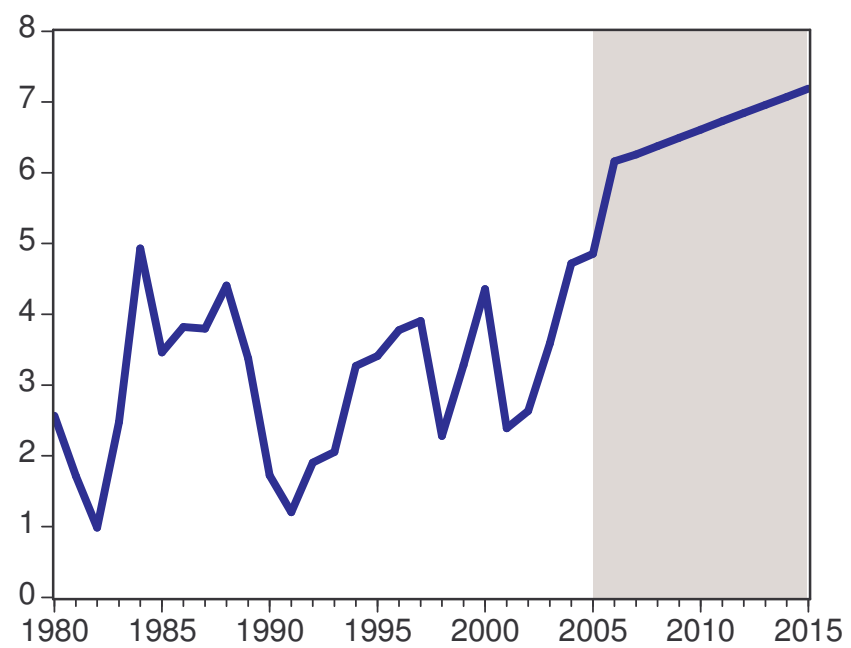

Table 3 elaborates the principal outlines of this scenario according to groupings, regions and some major countries. Under this scenario it becomes possible for the U.S. economy to grow at par with its long-term trend. The driver of U.S. economic growth would shift, however, from domestic spending, principally by households, to exports. This increase in export orientation would correspond to the shift of countries with large current account surpluses to greater reliance on domestic absorption. The latter would not lose growth momentum to the extent that they are able to reflate their economies. The United States would also benefit from increased trade prompted by income and productivity gains in other regions, particularly in Developing America, and from increased demand for its exports from Asia. 
TABLE 3

\begin{tabular}{|c|c|c|c|}
\hline \multicolumn{4}{|c|}{ Coordinated Growth } \\
\hline & 2001-05 & 2005 & $2006-15$ \\
\hline World & 3.7 & 5.0 & 6.9 \\
\hline Non U.S. (rest of the world) & 4.1 & 5.5 & 7.7 \\
\hline Developed & 2.0 & 2.5 & 3.0 \\
\hline United States & 2.4 & 3.5 & 3.0 \\
\hline Western Europe & 1.7 & 2.1 & 3.0 \\
\hline Japan & 1.0 & 0.8 & 3.0 \\
\hline Other Developed & 3.3 & 5.1 & 3.2 \\
\hline Eastern Europe & 3.8 & 3.9 & 7.5 \\
\hline Former USSR & 7.6 & 10.7 & 8.5 \\
\hline Developing (D'ing) & 6.0 & 8.1 & 10.6 \\
\hline D'ing Asia (exc.China) & 5.5 & 7.7 & 11.0 \\
\hline China & 8.9 & 9.6 & 10.0 \\
\hline D'ing America & 3.0 & 6.7 & 10.0 \\
\hline D'ing Africa & 5.2 & 7.7 & 12.0 \\
\hline Middle East & 6.0 & 7.2 & 11.0 \\
\hline
\end{tabular}

Other developed countries would enjoy similar accelerations in their trend rates of growth. Japan would experience a significant jump in growth, i.e., from 0.8 per cent in 2005 to a 3.0 per cent rate during 2006-2015. Western Europe would also increase growth, from 2.1 per cent in 2005 to 3.0 per cent during 2006-2015. As a result, its trade balance would move towards deficit, i.e., about two per cent of GNP, which would allow it to absorb an increase in imports from developing regions, such as Africa and Eastern Europe, while maintaining its level of imports from Asia and the Middle East.

Developing countries as a whole would benefit the most from the Coordinated Growth Scenario. Their projected average rate of growth would be 10.6 per cent during 2006-2015. Developing Asia and the Middle East are projected to do relatively well, i.e., attaining a growth rate of 11 per cent; and Developing Africa is projected to do even better, i.e., attaining a rate of 12 per cent. Africa's growth rate would thus be about 56 per cent higher than in 2005.

Developing America and China are projected to grow at a somewhat slower rate, i.e., 10 per cent. Such rapid rates of growth would be necessary for these countries to start 'catching up' with developed countries. But they would also be necessary to help these countries compensate for their stalled progress during the 1980s and early 1990s as well as to recoup the absolute losses that they suffered during part of that period.

The trend increase in the growth rates of developing countries is achieved through several means. Real resource transfers from developed countries constitute part of the explanation. Official Development Assistance is assumed to contribute to these transfers. Private foreign investment is also assumed to contribute, primarily in order to take advantage of more profitable opportunities in these growing economies. These resource flows would arise, in part, from the fact that the decline in the U.S. current account deficit of about four percentage points of its GNP would allow surpluses generated in other major countries to be channelled towards poorer countries. The decline in the U.S. deficit alone would represent, potentially, a huge absolute sum of about US\$ 2.5 trillion (in current dollars) available for 'redistribution' over the next ten years. In other words, the resolution of gross surplus and deficit imbalances among countries would coincide with a global redistribution of income. 
The increase in investment and income generation are assumed to lead to productivity increases and the diversification of production in developing countries. These countries could move away from import dependence on manufactures and an over-reliance on the export of primary commodities. Figure 23 depicts the projected changes in the trade balances of manufactures in Developing Africa, America and Asia.

In this process, not only would developing countries reduce their dependence on importing manufacturing but also they would avoid the accumulation of more external debt. In this scenario we assume that the injections of capital into the manufacturing sectors of developing countries would generate a capacity to increase exports to a level that would approximate their demand for imports. Results would vary, of course, from bloc to bloc, according to endowments and historical patterns of development. Developing countries rich in raw materials and energy supplies would not progress as quickly as others in enhancing their manufacturing capacities because the increased external demand for their commodities from other blocs would provide price signals that would motivate these countries to continue concentrating on primary sectors.

A meaningful shift from raw materials towards manufacture could take place in blocs such as Developing Africa and America. For Africa, it is assumed that the trade balance in manufactures would increase from more than a negative US\$80 billion in 2005 to about a positive US\$ 40 billion in 2015. Developing America's trade balance in manufactures would rise from about a negative US\$220 billion to about a negative US\$90 billion. The trade balance of Developing Asia (including China) would roughly double, from a surplus of over US\$300 billion to over US\$ 600 billion.

FIGURE 23

\section{Balance of Manufactures (US\$ billions)}

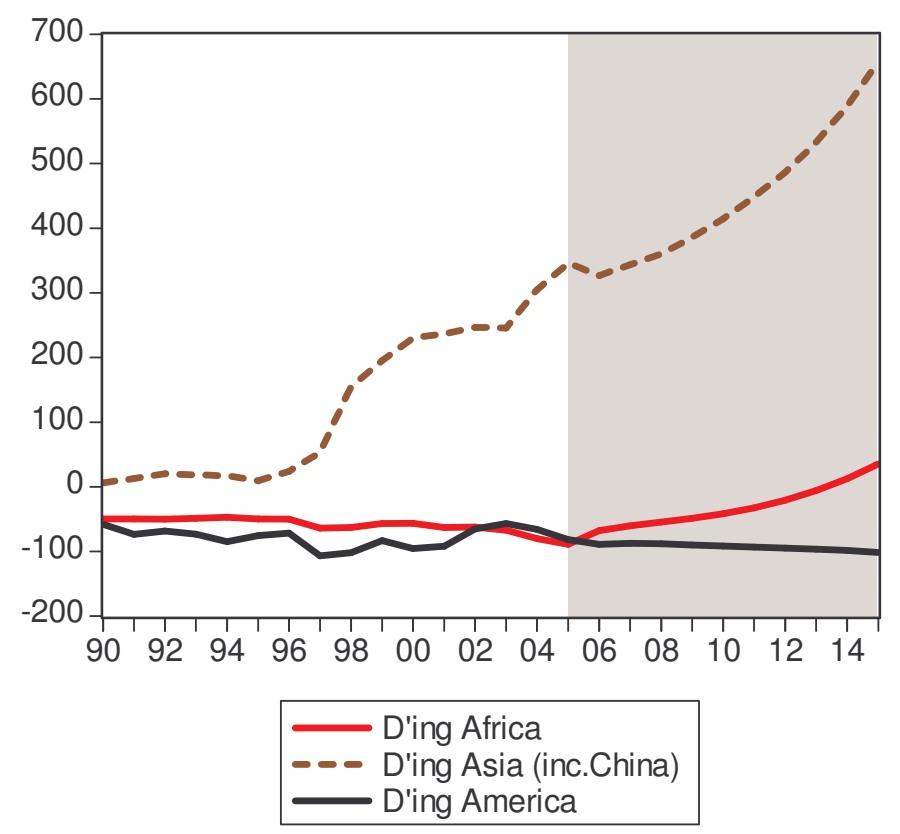

Along with productivity increases and greater diversification into manufacturing, developing countries would gain an enhanced capacity to engage in South-South trade integration. We depict the projected increases in South-South trade for Developing Africa, 
Developing America and Developing Asia in Figures 24-26. Since such intensification of trade integration would be based on increases in manufacturing output and productivity, it would not necessarily detract from trade with other regions.

The figures illustrate the projected increases in intra-regional trade as well as increases in trade with other regions and major countries (assuming that they achieve the growth rates projected in Table 3). Developing-country trade with developed countries would increase as a result of the former's enhanced capacity to produce manufactures. This would lead, in turn, to a rise in their demand for imports. Moreover, because of intensified South-South trade, developing countries that have been running large trade surpluses with developed countries would gain from more diversified trade opportunities. Thus, they would be less reliant on richcountry markets, such as the huge U.S. market.

Developing Africa now directs less than five per cent of its manufactured exports to its own regional market. Under the Coordinated Growth Scenario, this share would rise to over 25 per cent. The share of manufactured imports by Western Europe and other Developed Countries originating from Africa would also increase. Such an increase in growth-enhancing integration could provide a significant boost to income growth in the low-income countries of Africa. In Developing America, the share of its manufactured exports directed to its own regional market would rise from about 13 per cent to about 32 per cent. The share of manufactured imports by the United States originating in Developing America would also rise dramatically, i.e., from about 15 per cent to about 40 per cent.

The share of Developing Asia's manufacturing exports that would remain within the region would reach a staggering 70 per cent, up from about 52 per cent at present. The share of Asia's manufacturing trade with United States would be lower, however, primarily because of the intensification of U.S. trade relations with Developing America, and secondarily because other developed countries would be importing more manufactures from Asia.

FIGURE 24

\section{Manufactured Export Shares of Developing Africa}

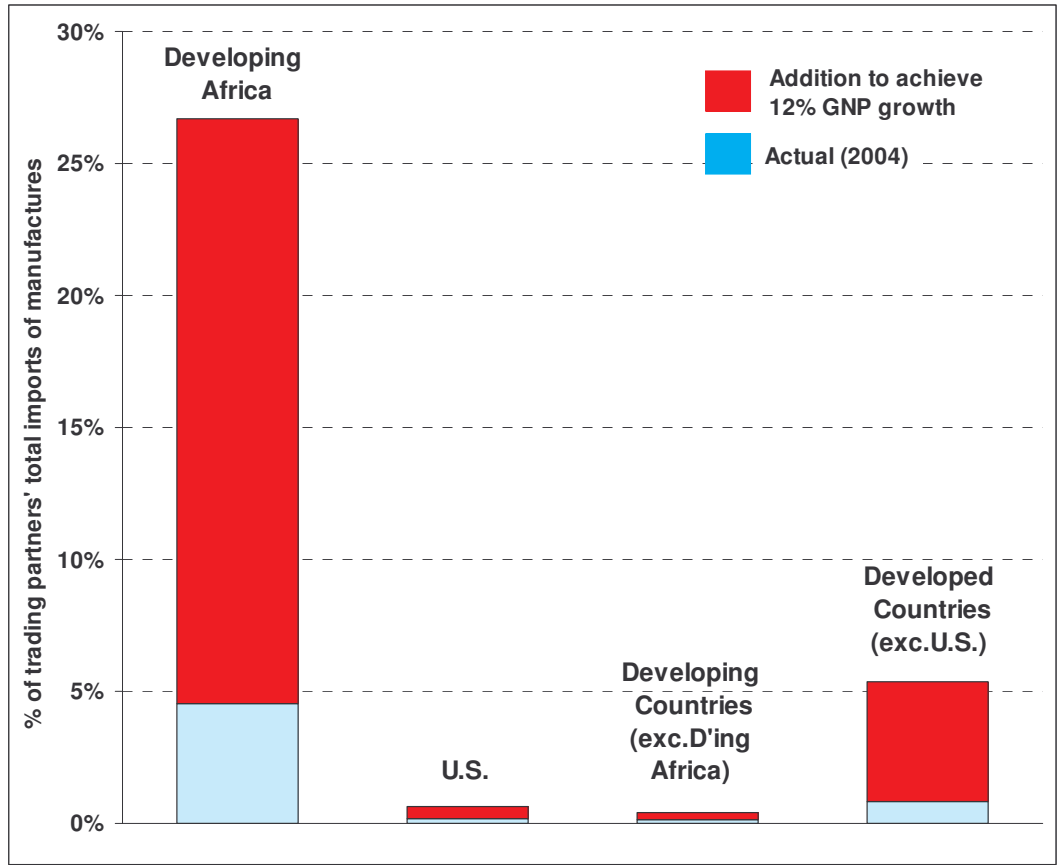


FIGURE 25

Manufactured Export Shares of Developing America

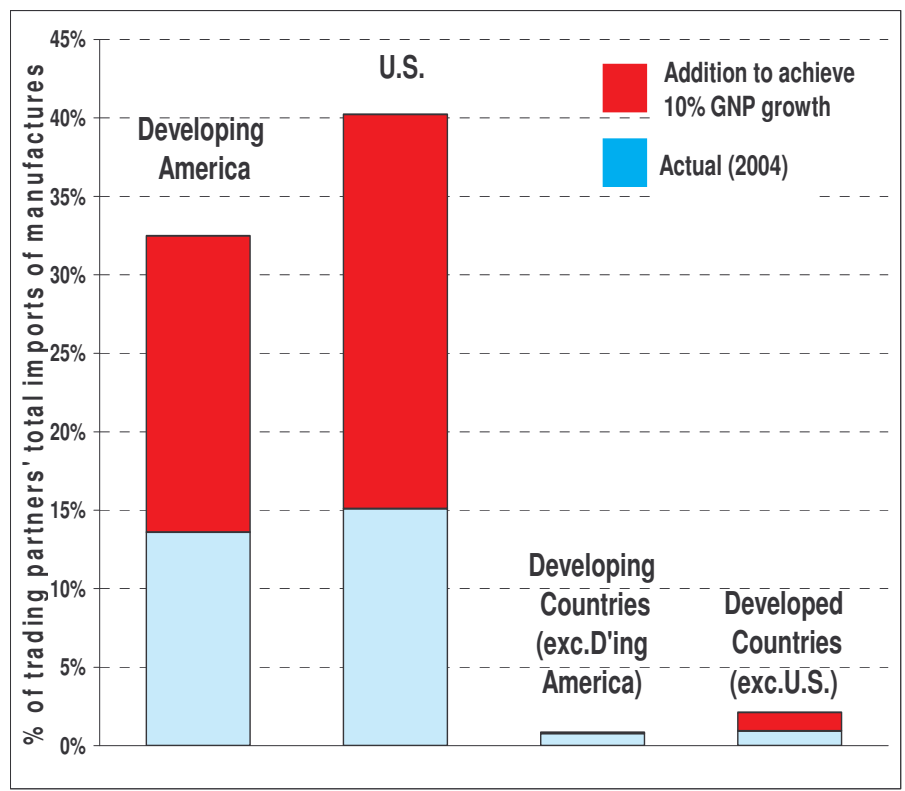

FIGURE 26

Manufactured Export Shares of Developing Asia (inc.China)

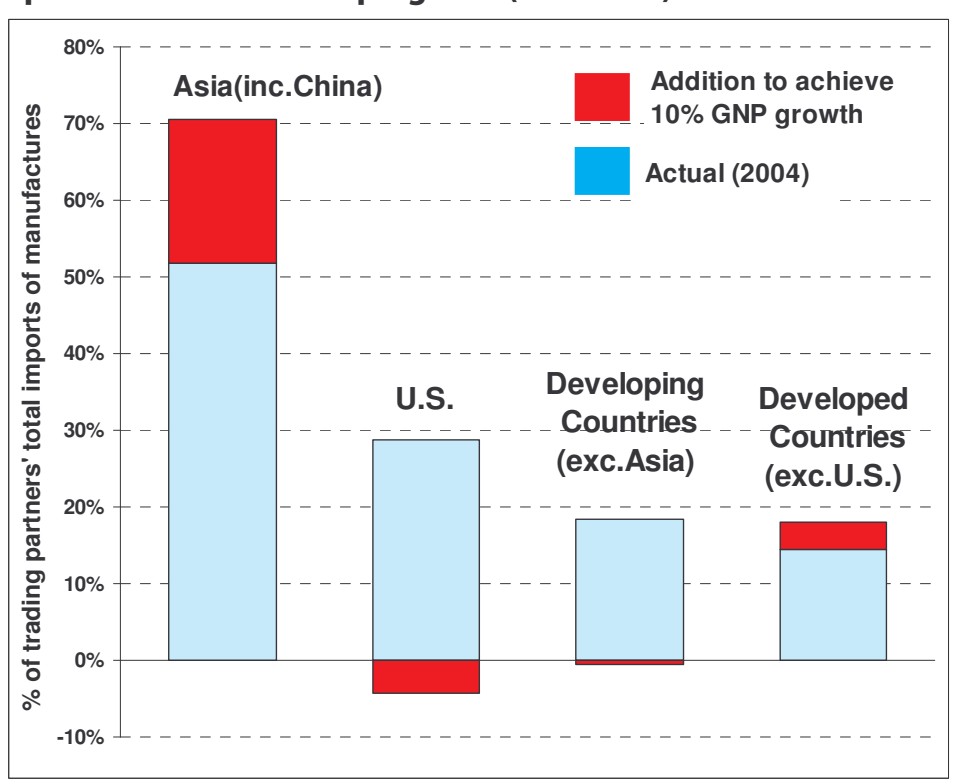

\section{Confronting the Energy Constraint}

The Coordinated Growth Scenario would have to confront the same binding constraint that the Consensus Growth Scenario faced, namely, an unavoidable increase in energy prices because of higher rates of economic growth. In order to have a successful outcome from the package of macroeconomic and structural reforms advanced by our third scenario, countries would have to mount a major effort to achieve greater energy efficiency. 
Various measures could be instituted in order to provide an adequate incentive structure for energy conservation. For example, a tax on energy use or tradable energy quotas as suggested by the Kyoto Convention could be part of such incentives. Figure 27 reflects two contrasting options: 1 ) an acceleration in the rate of growth of energy demand to about 5.5 per cent, which would be required in the Consensus Growth Scenario, assuming no improvement in energy efficiency and 2) a much slower growth in demand (i.e., an average of 1.8 per cent over ten years) as a result of substantial efficiency improvements triggered by conservation measures assumed in the Coordinated Growth Scenario.

FIGURE 27

\section{Energy Demand (Average rate of growth over 10 years)}

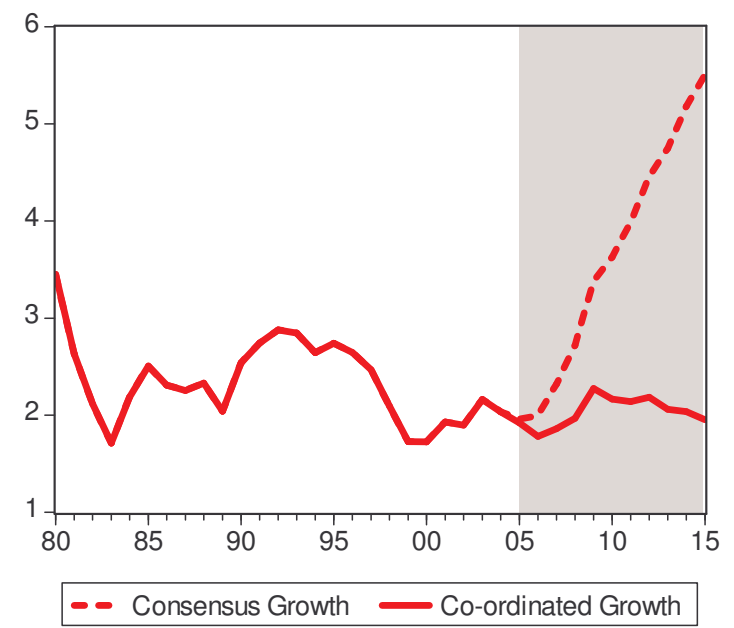

Under the Coordinated Growth Scenario, developing countries would benefit from price changes along two axes: 1) the containment of increases in energy prices due to technological advances in efficiency and 2) improved terms of trade attributable to their diversification into manufactured exports. Figure 28 shows the projected trend of energy prices relative to the prices of manufactured goods under both the Consensus Growth Scenario and the Coordinated Growth Scenario. Instead of rising to about 3.2 under the first scenario, the Energy Price Index relative to the price of manufactures would rise to 1.7 under the second.

FIGURE 28

Energy Price Index (Deflated by the price of manufactures)

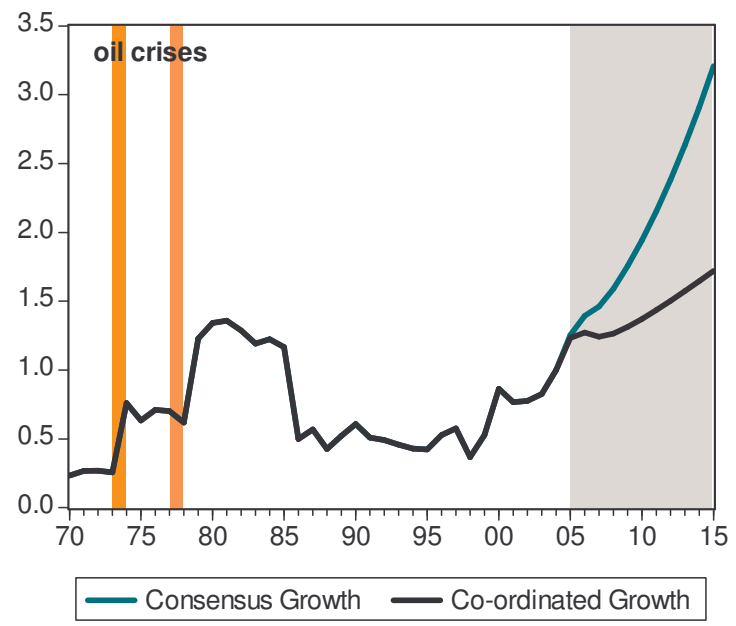




\section{CONCLUSION}

This paper has discussed three scenarios for the world economy based on the application of a world trade and income model. The first scenario presented what we call the 'Consensus Growth Forecast'. However, our estimates suggest that this scenario would lead to U.S. current account deficits of a negative 10 per cent of GDP by 2015. This increasing drag on aggregate demand would have to be compensated by increases in spending by either the U.S. domestic public sector or private sector. Since U.S. policymakers plan to bring down the government deficit, only the private sector could be expected to inject more aggregate demand into the economy. But we project that, within the private sector, investment by firms would grow to the point where their savings-investment gap would be only marginally negative. This stance would be consistent with their historic patterns.

This scenario would leave only the U.S. household sector as a source of stimulus for aggregate demand. Thus, a household-driven expansion would have to continue if the U.S. economy is assumed to keep growing at its trend rate. However, households would not continue spending indefinitely based on increased borrowing if their net worth continued to erode. For their wealth to be maintained, the price of their holdings of assets, such as stocks and housing, would have to increase at an unrealistically rapid pace in coming years. This implies that inevitably U.S. consumer spending would begin to slow. Once it does, there is no other source of aggregate demand that could step into the breach-in the absence of major policy changes.

This leads us to conclude that the most plausible scenario-in the absence of structural policies to re-adjust aggregate demand at the global level—would be a severe slowdown in the U.S. economy. This is our second scenario, which posits a slowdown in U.S. growth from 3.5 per cent in 2005 to -0.6 per cent in 2015. Thus, this scenario assumes a gradual, though still severe, drop of income. However, the slump could very likely occur much more abruptly. In this sense, we are still assuming a 'moderate' scenario.

Nevertheless, the impact of a slump in U.S. economic growth, reaching eventually a recession in 2012, would have damaging repercussions for the rest of the world. Other developed countries that trade extensively with the United States would be most adversely affected. Their growth would slow to a crawl and then follow the U.S. into recession. Developing countries that have built up some growth momentum in recent years would also suffer losses but would not lapse into economic stagnation. However, their growth rates would still be cut in half by 2015 . This outcome would lead inevitably to widening underemployment, falling real incomes and rising poverty.

We outline an ambitious, but feasible, alternative to this second gloomy scenario. The requirement, though, is the implementation of a major package of policy interventions-i.e., measures that imply reflation of the global economy and substantial structural change. We call this third scenario the 'Coordinated Growth Scenario' because it would require a heightened degree of policy coordination across countries. It would entail a redirection of global capital flows to poorer countries (which are starved of investment capital) so that significant increases in their income and spending could be generated.

For rich deficit countries, such as the United States, this scenario would involve policies that substitute strong growth in net exports for the current unsustainable growth of consumption. For countries running large current account surpluses, the opposite direction 
of policy change would be involved, namely, the promotion of greater domestic absorption and a resulting rise in domestic standards of living. Rising domestic absorption in high-income and middle-income countries that have run surpluses would substitute for the loss of demand from the U.S. economy, and would also help absorb growing exports from poorer countries.

This scenario posits economic growth of 3.0 per cent for developed countries in 2015, a rise from their rate of 2.5 per cent in 2005. However, developing countries would achieve a rate of growth in 2015-namely, 10.6 per cent-that could lay a solid basis for a sustained rise in human development and a substantial reduction of poverty. But simply redirecting capital flows towards poorer countries would not be sufficient. The 'Coordinated Growth Scenario' postulates augmented investment in manufacturing in developing countries, especially in order to overcome their dependence on the export of primary commodities. Investing in manufactures, in the context of increased income and spending, would enable these countries to boost their levels of productivity and progressively eliminate endemic trade deficits. Part of this effort would involve significantly increased South-South trade.

Like the 'Consensus Growth Scenario', the 'Coordinated Growth Scenario' would have to confront the probable adverse energy and environmental consequences of rapid rates of growth during the next ten years. In order to deal with this major stumbling block, the Coordinated Growth Scenario assumes that either a 'carbon tax' or tradable energy 'quotas', such as recommended by the Kyoto convention, would help constrain the growth in energy demand to an average 1.8 per cent per year. This would significantly moderate increases in energy prices and help support the projected rates of growth envisaged by the third scenario.

While the third scenario appears ambitious, we regard it as the only scenario of the three that would be both desirable and economically feasible. If we are correct in projecting a severe economic slowdown in the U.S. economy and extremely adverse knock-on effects for the world economy, a package of interventions similar to that envisaged in the third scenario would be necessary, we believe, to accelerate and sustain economic growth.

If other economic analysts can propose alternatives to our third scenario that could feasibly promote similar objectives, we welcome the opportunity to discuss and debate the advantages and disadvantages of such policy choices. However, one major point is clear to us: if the objective is to foster accelerated global growth based on greater equity and environmental sustainability, we cannot envisage an optimistic scenario in which major policy initiatives are not mounted. Leaving adjustments to the play of global market forces could not conceivably redress the severe macroeconomic imbalances now retarding the development of the world economy. 


\section{REFERENCES}

Alphametrics Ltd. 1987., 'Alphametrics Model of the World Economy' mimeo.

Bacha, E. 1990. 'A Three-Gap Model of Foreign Transfers and the GDP Growth Rate in Developing Countries', Journal of Development Economics, 32, pp. 279-296.

Bill, M. 2001. 'Can American Recovery be Sustained?', UBS Research Paper, October.

Congressional Budget Office (CBO). 2006., The Budget and Economic Outlook: Fiscal Years 2007 to 2016 ', January.

Cripps, F. and W. Godley. 1978. 'Control of Imports as a Means to Full Employment and the Expansion of World Trade: the UK's Case'. Cambridge Journal of Economics. Vol 2, No. 1, pp. 327-334.

FitzGerald, E.V.K. and R. Vos (eds). 1989. 'Financing Economic Development: A Structural Approach to Monetary Policy.' Aldershot \& Brookfield: Gower.

FitzGerald, E.V.K., K. Jansen and R. Vos 1992., External Constraints in Private Investment Decisions in Developing Countries, ISS, The Hague. (to be published in J. W. Gunning et al. (eds): Trade, Aid and Development. Essays in Honor of Hans Linnemann, MacMillan, London.

FitzGerald, E.V.K. 1993. 'The Macroeconomics of Development Finance: A Kaleckian Analysis of the Semi-Industrialized Economy', MacMillan Press and ISS, New York.

Godley, W. 1995. 'U.S. Foreign Trade, the Budget Deficit, and Strategic Policy Problems' A Background Brief, "Levy Economics Institute Working Paper No. 138.

1996. 'Money, Finance, and National Income Determination: An Integrated Approach'. Levy Economics Institute Working Paper No. 167.

1999. 'Seven Unsustainable Processes. Medium-Term Prospects and Policies for the United States and the World'. Levy Economics Institute Strategic Analysis Series, September.

2000. 'Interim Report: Notes on the U.S. Trade and Balance of Payments Deficits'. Levy Economics Institute Strategic Analysis Series, December.

Godley, W. and A. Izurieta. (2001a). 'The Developing U.S. Recession and Guidelines for Policy'. Levy Economics Institute, October.

June.

(2001b). 'As the Implosion Begins?' Levy Economics Institute Strategic Analysis Series,

Godley, W., and B. Martin. 1999. 'How Negative Can U.S. Saving Get'. Policy Note, Levy Economics Institute.

Godley, W. and F. Cripps. 1983. 'Macroeconomics'. Oxford University Press. Oxford.

Godley, W., and G. McCarthy. 1998. 'Fiscal Policy Will Matter.' Challenge, Vol. 41, No. 1, January/February: 38-54.

Izurieta, A. 2005. 'Hazardous Inertia of Imbalances in the US and World Economy', Economic and Political Weekly, August.

Kaldor, N. 1939. 'Speculation and Economic Stability', The Review of Economic Studies, Vol. 7, No. 1 (Oct., 1939), 1-27.

Kaldor, N. 1932. 'A Case Against Technical Progress', Economica, No. 36 (May, 1932), 180-196. 
Kaldor, N. 1986. 'Limits on Growth', Oxford Economic Papers, New Series, Vol. 38, No. 2 (Jul., 1986), 187-198.

Kalecki, M. 1976. 'Essays on Developing Economies', Sussex: Harverster Press.

Keynes, J. M. (1930; repr.1971) A Treatise on Money. The Pure Theory of Money, London \& New York: MacMillan \& Cambridge University Press for the Royal Economic Society.

(1936; repr.1997) The General Theory of Employment, Interest and Money, Amherst: Prometheus Books, Great Minds Series, Paperback.

Lewis, A. 1954. 'Economic Development with Unlimited Supply of Labour', in Agarwala, A. and S. P. Singh (eds) (1958) 'The Economics of Underdevelopment'. Oxford: Oxford University Press.

Martin, B. 2001. 'Can American Recovery Be Sustained?' UBS Research Papers. October 22.

Papadimitriou, D., A. Shaikh, C. Dos Santos and G. Zezza. 2003. 'Deficits, Debts and Growth: A Reprieve but not a Pardon'. Levy Economics Institute Strategic Analysis Series, October.

2004. 'Is Deficit-Financed Growth Limited?: Policies and Prospects in An Election Year'. Levy Economics Institute Strategic Analysis Series, April.

2005. 'How Fragile Is the U.S. Economy,' Levy Economics Institute Strategic Analysis Series, March.

Taylor, L.(ed) (1993) 'The Rocky Road to Reform. Adjustment, Income Distribution, and Growth in the Developing World', MIT Press, Cambridge.

U.S. Government Printing Office 2006., 'Economic Report of the President' ,Washington D.C. February.

Vos, R. 1994. 'Debt and Adjustment in the World Economy: Structural Asymmetries in North-South Interactions', London: Macmillan; in association with the Institute of Social Studies, Netherlands. 


\section{APPENDIX: COUNTRY BLOCS}

1 Western Europe: Germany, Austria, Belgium, Denmark, Finland, France, Greece, Iceland, Ireland, Italy, Luxembourg, Netherlands, Norway, Portugal, Spain, Sweden, Switzerland, United Kingdom.

2 Other Developed: South Africa, Canada, Australia, New Zealand, and Israel.

3 China: including Mainland, Hong Kong \& Macao.

4 Developing Asia: developing Oceania and former (Soviet) Central Asian States; but excludes China: Afghanistan, Armenia, Azerbaijan, Bangladesh, Bhutan, Brunei Darussalam, Cambodia, Fiji, Georgia, India, Indonesia, Kazakhstan, Kiribati, Korea Democratic People's Republic, Republic of Korea, Kyrgyzstan, Lao People's Democratic Republic, Malaysia, Maldives, Mongolia, Myanmar, Nepal, Pakistan, Papua New Guinea, Philippines, Samoa, Solomon Islands, Singapore, Sri Lanka, Tajikistan, Thailand, Tonga, Turkmenistan, Uzbekistan, Vanuatu, and Vietnam.

5 Middle East: Bahrain, Cyprus, Iran, Iraq, Jordan, Kuwait, Lebanon, Oman, Qatar, Saudi Arabia, Syria, Turkey, UAE, and Yemen.

6 Developing America: South \& Central America and the Caribbean plus North America minus Canada and U.S.: Antigua, Argentina, Bahamas, Barbados, Belize, Bolivia, Brazil, Chile, Colombia, Costa Rica, Dominica, Dominican Republic, Ecuador, El Salvador, Grenada, Guatemala, Guyana, Haiti, Honduras, Jamaica, Martinique, Mexico, Netherlands Antilles, Nicaragua, Panama, Paraguay, Peru, Puerto Rico, St. Kitts and Nevis, St. Lucia, St. Vincent and the Grenadines, Suriname, Trinidad \& Tobago, Uruguay, and Venezuela.

7 Developing Africa, excluding South Africa: Algeria, Angola, Benin, Botswana, Burkina Faso, Burundi, Cameroon, Cape Verde, Central African Republic, Chad, Comoros, Democratic Republic of Congo (former Zaire), Congo Rep. of., Cote d'Ivoire, Djibouti, Egypt, Equatorial Guinea, Eritrea, Ethiopia, Gabon, Gambia, Ghana, Guinea, Guinea-Bissau, Kenya, Lesotho, Liberia, Libya, Madagascar, Malawi, Mali, Mauritania, Mauritius, Morocco, Mozambique, Namibia, Niger, Nigeria, Rwanda, Senegal, Seychelles, Sierra Leone, Somalia, Sudan, Swaziland, Tanzania, Togo, Tunisia, Uganda, Zambia, and Zimbabwe.

8 Eastern Europe: European states of the former USSR: Albania, Bulgaria, former Czechoslovakia (Czech Rep., Slovakia), Hungary, Poland, Romania, Slovakia (after 1992), and Former Yugoslavia (Bosnia and Herzegovina, Croatia, Macedonia, Serbia and Montenegro, Kosovo, Slovenia).

9 Former USSR: Former USSR republics geographically located in Europe: Belarus, Estonia, Latvia, Lithuania, Republic of Moldova, Russian Federation, Ukraine. 


\section{NOTES}

1. Consensus Economics, founded in 1989, is the world's leading international economic survey organisation and polls more than 700 economists each month to obtain their forecasts and views. (http://www.consensuseconomics.com)

2. An analytical description of the new framework is available upon request and will soon be published as a technical paper.

3. Regarding the debate about the roles of official development assistance and foreign direct investment, the empirical evidence suggests that once conditions improve, private flows tend to follow suit (FitzGerald, Jansen and Vos, 1992). In this paper, financing is an issue that arises when a policy-driven scenario is discussed (scenario 3 in section 3 ) and the inflow of FDI is assumed to respond to ensuing growth.

4. While this paper goes to press, BEA's annual release of the International Investment Position of the U.S. revealed that the net liability position at year-end 2005 remained 20 per cent of GDP, in contrast to our own estimate of 30 per cent of GDP. However, the BEA estimate is based on an extraordinary appreciation of one trillion dollars of U.S. stocks abroad. Such an appreciation does not materially affect, however, the increase in the U.S. external debt. Such changes in valuation become relevant only when assets are converted into cash. If this happened, there would be a corresponding price change in the opposite direction. Thus, we retain our own estimate of 30 per cent of GDP for the net liability position of the United States, which was based on accounting for the accumulation of U.S. deficits and the impact of dollar appreciation.

5. See the BEA's International Position Table and the Fed's 'Flow of Funds' balance sheets and the reconciliation tables B.102 and R.102.

6. Total financial liabilities of the U.S. Government exceed its financial assets roughly by a factor of four. In the case of corporations, we have compared external liabilities with the total value of assets (financial and physical), which is registered in their balance sheets. For the aggregate of government institutions, such an approach is not possible because of accounting conventions. It is not possible, for example, to include physical assets at market prices so the Flow of Funds tables register only financial assets. Our estimates of assets and liabilities of the government in the future incorporate the Congressional Budget Office (CBO) assumption that the deficit will shrink and eventually turn into a surplus. Thus, beginning in 2013, the ratio of foreign debt to government assets will start to decline slightly from 90 per cent.

7. It makes no macroeconomic sense whatsoever to think that the three main sectors outlined above can conduct their own adjustment process independently of one another. Such an assumption highlights an inherent contradiction of most conventional approaches to macro modelling. Either 1) the economy grows as projected and the private sector has to spend beyond its means to make this happen or 2) the private sectors reins in its spending and the projected rate of growth will not occur.

8. $\mathrm{CBO}$ documents express the deficit of the Federal Government in fiscal years while the accounting identity derived above requires using the General Government (Federal plus Central and Local Government) deficit in calendar years. In 2005, the latter was nearly US\$ 500 billion while CBO reported a Federal deficit for the 2005 fiscal year of US\$ 320 billion. In our estimates, we have taken the trend assumed by the $\mathrm{CBO}$ and adjusted the deficit of the non-Federal government in the same fashion.

9. By postulating a small deficit for the corporate sector when, in fact, its historic average has been a surplus of about 0.5 per cent of GNP, we are implying that the personal sector will end up in a slightly less precarious financial position than would otherwise be the case.

10. We deflated the prices of both stocks and housing by the GDP deflator for the period through 2005 and by the GDP deflator estimate published by the CBO for the projected period until 2015.

11. This category includes North African oil exporters but excludes South Africa, which is grouped with Other Developed Countries. In the current model we use the statistical framework inherited from the 'standard' grouping of countries established in the 1970s and still present in the UN trade matrices. In a new and expanded version of our world model, we will use the full Comtrade dataset provided by the UN-DESA in order to group countries in a more consistent way.

12. The simultaneous equation solution of the energy subset of the world model incorporates supply and demand conditions. The supply side incorporates the long-run expectations of production, physical capacities and prices by governmental institutions and oil companies. The demand side is based on long-run patterns of energy requirements relative to output (with the de-trended elasticity of income being close to one in most blocs) and assumptions about energy-saving improvements that respond to relative price increases (with elasticities being in the range of 15 to 30 per cent, and being higher in net oil importing blocs than oil exporters).

13. Each point on the graph represents the average of the previous 10 years of growth rates. 
International Poverty Centre SBS - Ed. BNDES, $10^{\circ}$ andar 70076900 Brasilia DF Brazil

povertycentre@undp-povertycentre.org www.undp.org/povertycentre

Telephone +55 6121055000

Fax +55 6121055001 